\title{
VALİ REBIII KARATEKİN DÖNEMİNDE TARİHÎ ESER VE TURIZMM ÇALIŞMALARININ KONYA BASININA YANSIMALARI
}

\author{
THE REFLECTIONS TO THE PRESS OF KONYA OF THE \\ HISTORICAL MONUMENTS AND TOURISM WORK IN THE \\ PERIOD OF GOVERNOR REBIII KARATEKIN
}

Çă̆atay BENHÜR*

\begin{abstract}
$\ddot{O} z$
Mehmet Rebii Karatekin, 1960 yılı sonlarında Konya Valiliğine atanmıştır. Önceden görev yaptığı yerlerde tarihi eser ve turizme olan ilgisi ile bilinen Karatekin, Konya da göreve başlar başlamaz aynı konuları ele almıştır. Konya'nın tarihinden gelen kültürel mirasını geliştirmek, tarihi eserlerin bulunması, korunması ve onarlmasın să̆lamak öncelikli hedeflerinden birisi olmuştur. Müze ve müzecilik alanında da yeni uygulamalar getirmek isteyen Vali Rebii Karatekin, bir diğer ilgi alanı olarak da turizmi belirlemiştir. İkinci Dünya Savaşından sonra dünyada artan turizm ve Konya'nın turizm potansiyeli göz önüne alındı̆̆ında Karatekin'in yaptığı çok önemli bir girişimdir. Dönemin Konya basını, yeni valinin çalışmalarını kısa sürede takdir etmiş ve sahiplenmiştir. Tarihi eserler ve turizm konusunda pek çok destekleyici, tanıtıcı haberler yapılmış, makaleler yazılmıştır. Ortaya çıkan aksaklıklar eleştirilmiş, çözüm yolları önerilmiştir. Vali Rebii Karatekin ve Konya basınının önemle üzerinde durduğ u ve çalıştığı konular kısa süre içerisinde kent halkı tarafından da benimsenmiş ve desteklenmiştir. Bu çalışmada, Vali Rebii Karatekin döneminde Konya'da gerçekleştirilen tarihi eser ve turizm çalışmalarının kent basınına yansımaları anlatılmaya çalışılacaktır.
\end{abstract}

\section{Anahtar Kelimeler}

Çatalhöyük, Konya, Müze, Rebii Karatekin, Tarihi Eser, Turizm, Vali.

\begin{abstract}
Mehmet Rebii Karatekin was appointed to the governor of Konya in the late 1960's. Karatekin, known for his interest in historical work and tourism in places where he had previously served, addressed the same issues in Konya, at the start of his assignment. Finding, preserving and repairing historical monuments and developing the cultural heritage of Konya's history has been one of the primary goals of him. Governor Rebii Karatekin, who wants to bring new approaches in the management of museums, has also identified tourism as another area of interest. It has been a very important undertaking by Karatekin when considering Konya's tourism potential after World War II. The press in Konya appreciated and embraced the work of the new governor in a short period of time. There are many supporting articles written and introductory news published about historical monuments and tourism. The resulting mishaps have been analyzed and solutions have been
\end{abstract}

Yrd. Doç. Dr., Selçuk Üniversitesi, Edebiyat Fakültesi, Tarih Bölümü Öğretim Üyesi, cbenhur@selcuk.edu.tr 
proposed. The governor Rebii Karatekin and Konya media have been strongly supported by the people of the city in a short period of time. In this study, explanations of which will be the reflections to the city press of the historical monuments and tourism works carried out in Konya during the assignment of Rebii Karatekin.

\section{Keywords}

Çatalhöyük, Governor, Historical Artifacts, Konya, Museum, Rebii Karatekin, Tourism. 


\section{GİRIŞ}

Mustafa Suphi Bey ile Naciye Hanımın oğulları Mehmet Rebii Karatekin, 1906 ilkbaharında İstanbul'da dünyaya gelmiştir ${ }^{1}$. İlk, orta ve lise öğrenimini İstanbul'da tamamladıktan sonra İstanbul Üniversitesi Hukuk Fakültesinden mezun olmuştur ${ }^{2}$. 1.1.1924 tarihinde Şark Demiryolları Emtis Ticariye Kalemi Memur Muavinliği ile başladığı çalışma hayatına, sırası ile İstanbul 3. ve 2. İcra Dairelerinde kâtip namzetliği ve kâtiplik (1928-30), Manisa Maiyet Memurluğu (1930-31), Kütahya Nüfus Müdürlügü (1931-32), Mardin Nüfus Müdürlüğü (193233), Karaisalı Kaymakamlığı (1933-35), Menemen Kaymakamlığı (1935-36), Gölcük Kaymakamlığı (1936-37), Şile Kaymakamlığı (1937-39), Fatih Kaymakamlığ1 (1939-43), Tarsus Kaymakamlığı (1943-44), Mahalli İdareler Şube Müdürlüğü (1944), Mahalli İdareler Daire Başkanlığı (1944-45), Burdur Valiliği (1945-47), Sivas Valiliği (1947-50), Ordu Valiliği (1950-51), Hatay Valiliği (1951-54), İller Bankası İdare Meclis Azası (1954-55), Kastamonu Valiliği (195560), Tekirdağ Valiliği (1960) görevleri ile devam etmiştir³. 3 Kasım 1960 tarihinde Konya Valisi olarak göreve başlayan Karatekin, 4 Haziran 1964 tarihinde emekli olmuştur4.

Rebii Karatekin'in vali olarak atandığı Konya'nın 1960 yılı itibarı ile genel görünümünden kısaca bahsetmemiz gerekirse, 1928 yılında 14 ilçenin bağlı olduğu Konya vilayetine, 1953'te Yunak, 1954'te Kulu, 1957'de Doğanhisar, 1959 yılında da Sarayönü ilçeleri eklenmiştir ${ }^{5} .1960$ verilerine göre Konya vilayetinin yüzölçümü 46.082 kilometrekare, nüfusu ise 982.422 kişidir6.

Tarıma elverişli, geniş ekili dikili alanlara sahip Konya'da 1950 yılına kadar traktör kullanımı yeterince gelişmemiştir. İkinci Dünya Savaşından sonra toparlanmaya başlayan Konya tarımı, 1958 yılında kullanılan biçerdöver sayısı olarak Türkiye birincisi, traktör sayısı olarak da ikinci sırayı almıştır. 1960 itibarı ile Konya'da üretilen buğday yıllık 983.352 tona ulaşmıştır. Aynı yıl Konya'da 62.500 hektar bağ ve 2.6 milyon koyun, 613.000 tiftik keçisi, 342.000 sığır bulunmaktadır. Yıllık süt üretimi ise 160.000 tona ulaşmıştır7.

\section{Yılında Konya'da Tarihî Eser ve Turizm Çalışmaları}

Rebii Karatekin hakkında Konya basınında ilk haber, 25 Ekim 1960 tarihinde çıkmış ve Tekirdağ Valisi olarak görev yapan Karatekin'in, Konya'ya atandığı bildirilmiştir. Aynı haberde, yeni valinin kısa özgeçmişi de verilmiştir. Yeni vali hakkındaki haberler ertesi gün kısa da olsa devam etmiş ve Karatekin'in 16 yıllık tecrübeli bir vali olduğu vurgulanmıştır9.

Rebii Karatekin'in Emekli Sicil Dosyasında bulunan Nüfus Hüviyet Cüzdanında; doğum tarihi Rumî 16 Mayıs 1906, Hicri 26 Nisan 1906 tarihine denk gelecek şekilde 2 farklı tarih olarak yazılmıştır. Bu yüzden biz, Karatekin'in doğum tarihi olarak ilkbahar 1906 tabirini kullanmayı uygun bulduk. Ayrıntı için bkz. T.C. Emekli Sandığı Genel Müdürlüğü Arşivi, Dosya No: 06.145.560, Nüfus Hüviyet Cüzdanı belgesi.

2 Mehmet Ali Uz, Karatekin, Rebii, Konya Ansiklopedisi, Konya Büyükşehir Belediyesi Yayınları, C.5, Konya 2013, s. 120.

T.C.Emekli Sandığı Genel Müdürlüğü Arşivi, 06.145.560, Rebii Karatekin Hizmet Cetveli belgesi.

Ayn belge.

Ahmet Özcan - Mustafa Göğer- vd., 1984 Sonrası Konya, Dönmez Ofset, Ankara 1988, s62.

http://kutuphane.tuik.gov.tr/pdf/0015137.pdf.

Yaşar Semiz, Cumhuriyet Döneminde Konya'nın İktisadî Durumu (1923-1960), Milli Mücadeleden Günümüze Konya (1915-1965), C.I, T.C. Konya Valiliği İl Kültür Müdürlügü Yayınları, Konya 1999, s.142-152.

8 Yeni Konya, 25 Ekim 1960, s.1.

9 Yeni Meram, 26 Ekim 1960, s.1. 
Haberlerde dikkat çeken bir husus ise yeni valinin tam olarak ne zaman kente gelerek görevine başlayacağının bilinmediğidir.

Konya basınından öğrenildiğine göre, Vali Rebii Karatekin, 3 Kasım 1960 tarihinde Konya'ya gelerek görevine başlamıştır. Bu durum ertesi günkü gazetelerin ilk sayfasında kendisine yer bulmuştur ${ }^{10}$. Rebii Karatekin'in Konya Valisi olmasından sonra, Konya basınında tarihi eser ve turizme dair ilk haber o yıl Mevlana Celaleddin Rumî'nin vefatının 687.yılı dolayısıyla düzenlenecek olan Mevlana İhtifali ile ilgilidir. Haberde, vali başkanlığında oluşturulan heyetin çalışmalara başladığı ve gelecek olan misafirleri memnun etmek için çeşitli düzenlemelerin yapıldığından bahsedilmektedir ${ }^{11}$.

18 Kasım 1960 tarihinde ise Konya basınında, İplikçi Camisinden boşaltılan tarihi eserlerin sergileneceği büyük bir müze yapımına başlanacağı haberi yer almıştır. Verilen bilgiye göre, 126 bin lira ihale bedeli olan müze, Sahip Ata Külliyesi civarına yapılacaktır ve bitimiyle birlikte Konya'daki müze sayısı 5'e yükselecektir ${ }^{12}$.

Bilindiği gibi tarihi eserlere gösterilen ilgi, onların bulunması, onarılması ve korunması bir genel kültür meselesidir. Herhangi bir toplumda genel kültür eksikliğinin görüldüğü alanların başında, eski/tarihi eser politikaları gelmektedir. Bu çalışmanın ana eksenini oluşturan konuların da genel kültürle doğrudan bağlantısı vardır. Metin Berberoğlu, Yeni Konya Gazetesinde yazdığı Kültür Seviyesi adlı makalesi ile 3 Aralık 1960 tarihinde tam da bu konuyu ele almiştır ${ }^{13}$.

Konya basınında 1960 yılında çıkan tarihi eserler ve turizmle ilgili haberlere göz atmaya devam edildiğinde, Koyunoğlu Müzesinin 1961 tarihinde yeni bir binaya kavuşacağ haberi $^{14}$ ile birlikte yine sevindirici bir havadis olarak, o dönemde Konya'nın ilçelerinden birisi olan Karaman'da, Karamanoğlu Mehmet Bey'in büyük bir heykelinin dikilmesi için çalışmalara başlandığı ve konu ile alakalı yürütücü bir heyet kurulduğu haberi basına yansımıştır ${ }^{15}$.

\section{Yılında Konya'da Tarihi Eser ve Turizm Çalışmaları}

Yeni yılın ilk günlerinde, Muzaffer Erdoğan, 6 Ocak 1961 tarihinde Yeni Konya Gazetesinde, Konya Tarih ve Folklorunda Meram başlıklı makalesine; Konya'nın eski ve ünlü bir mesiresi olan Meram'ın geçmiş devirleri, Tarihin en eski çă̆larına kadar indiği muhakkak gibidir. Muhtelif vesilelerle rastlanan yazll Eti ve Frig bakiyeleri, Roma ve Bizans kalıntılarl; buranın mezkûr çă̆ların oldukça önemli bir yerleşme bölgesi olabileceğini hatırlatmaktadır... şeklinde giriş yapmış ve makalenin devamında kronolojik olarak Meram'ın tarihinden bahsetmiştir. Muzaffer Erdoğan, Meram tarihinden bahsederken bölgede bulunan önemli tarihi eserlere de sık s1k vurgular yapmıştır ${ }^{16}$. Görüldügü üzere dönemin Konya basını, zaman zaman okurlarını Konya'nın muhtelif yerlerindeki tarihi perspektif ve tarihi eserler konusunda bilgilendirmektedir.

Vali Rebii Karatekin'in yakından ilgilendiği ve Devlet Bakanlığına müracaat edildiği haberlerinin basına yansıdığı konu ise Karaman'da bulunan Hatuniye, Mader-i Mevlana ve İbrahim Paşa Medreselerinin tamir edileceği meselesidir. Habere göre, onarımlar Haziran ayındaki dil bayramına yetiştirilecektir. Yine aynı habere göre; onarımı tamamlandıktan sonra Hatuniye Medresesinde bir eski eserler müzesi açılacaktır ${ }^{17}$.

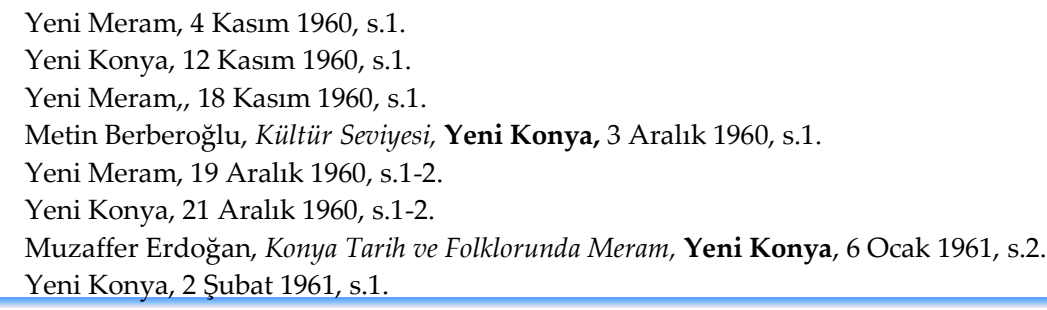


1960'1 y yılların basını incelendiğinde, Konya'da eskiden yapılmış yapıları yaşatmak amacıyla halkın bir araya gelerek birtakım faaliyetlere giriştiği de gözlemlenmiştir. Seydişehir Gökhüyük Köyünde, köy halkının Gökhüyük Camiini onarmak ve yaşatmak amacıyla kurdukları dernek bu faaliyetler arasında sayılabilir. Kurulan derneğin nizamnamesi basında yayımlanmış ve hem kuruluş prosedürü tamamlanmış hem de derneğin reklamı yapılmıştır ${ }^{18}$.

Tam olarak tarihi eser statüsünde olmasa da, Konya'da bulunan Atatürk Anıtının onarılacağı haberinin dönemin basınına yansıması, bu çalışmada, haberle birlikte verilen bilgilerin orijinalliği açısından kendisine yer bulmuştur. Habere göre, kaidesi Mimar Muzaffer tarafından yapılmaya başlanan, kendisinin vefatı dolayısıyla Mimar Talih Ülkü tarafından tamamlanan, Heykeltıraş Krippel ${ }^{19}$ tarafından yapılmış olan Atatürk heykeli esaslı bir onarım görecektir ${ }^{20}$.

İçişleri Bakanlığının Konya Valiliğine gönderdiği bir genelgede özetle, ülke ekonomisine katkı sağlamak amacıyla turizm faaliyetlerinin arttırılması ve teşvik edilmesi hususunda Konya Valiliği ve Belediyesinden görüş istenmiştir. Konya basınına göre de ilgili kurumlar yaptıkları çalışmayı bakanlığa gönderirken; Konya'nın bu konudaki en önemli katma değer sağlayabilecek unsurunun Mevlana Müzesi Külliyesi olduğunu bildirmişler ve buranın istenilen düzeyde katkı sağlaması için 5 milyon liralık bir düzenlemeye ihtiyaç olduğunu bildirmişlerdir ${ }^{21}$.

Bu yıl bir müze daha açılıyor başlığı ile verilen haberde, Sahip Ata Camisinin batı kısmında yapılmakta olan yeni müze binasının inşaatının Haziran ayına kadar bitirileceği, burada Konya Klasik Eserler Müzesi adıyla kentin 5. müzesinin açılacağı bilgisi verilmiştir22. 1961 yılı Mart ayında özellikle Yeni Konya Gazetesinde tarihi eserler konusu ile ilgili haberler çıkmaya devam etmiştir. Bu yıl beş eski eser onarllıyor başlıklı haberin tafsilatında, Konya Eski Eserleri Sevenler Derneği tarafından; Sırçalı Mescit, Halka Beguş Türbesi ve Mescidi, Abdülmümin Mescidi, Cemal Ali Dede Türbesi, Hasbey Darülhuffazının onarılacağı, bu eserlerden bazılarının onarımının bittiği, bazılarının devam ettiği, bazılarınınsa planlandığı bildirilmiş ve derneğin vatandaşların maddi yardımlarını kabul ettiği yazılmıştır. Önemli bir nokta olarak da eserlerin onarımının Konya Müzeler Müdürlüğünün nezaretinde yapılıyor olduğu vurgulanmıştır. Gazetenin aynı gün ve aynı sayfasında, Bayramda Müzeler Açı adlı başlıkla verilen haberde de bayram boyunca Konya müzelerinin ziyarete açık olduğu okurların bilgisine sunulmuştur ${ }^{23}$. İlerleyen zamanda Konya Çatalhöyük kazılarını ${ }^{24}$ da yürütecek olan ve o dönemde Ankara İngiliz Arkeoloji Enstitüsü Müdür Yardımcısı, Arkeolog James Mellaart'ın²5, Hacılar Köyü kazılar1 $^{26}$ ile ilgili Konya basınında neredeyse yarım sayfanın tamamını kaplayan bir haber çıkması ve Hacılar Höyük Kazısında bulunan buluntuların ayrıntılı olarak değerlendirilmesi de, dönemin Konya'sında bu tip olaylara bakışı ve basının genel havasını vermesi açısından önemlidir ${ }^{27}$. Tüm bu olumlu gelişmelerin yanında, Mart ayının son günlerinde çıkan olumsuz bir habere göre, yıkılma tehlikesi içerisinde olan Alâaddin Camii dış duvarlarının onarımı için

\footnotetext{
Yeni Meram, 4 Şubat 1961, s.4.

19 Heinrich Krippel, Avusturya'lı heykeltıraş, ressam, illüstratör. Ayrıntılı bilgi için bkz. Krippel, Heinrinck, Ana Britanncica, C.13, Ana Yayıncilık, İstanbul, 1989, s.626.

Yeni Meram, 16 Şubat 1961, s.1.

Yeni Meram, 18 Şubat 1961, s.1-2.

Yeni Konya, 12 Mart 1961, s.1.

Yeni Konya, 14 Mart 1961, s.1.

Ian Hodder, Çatalhöyük The Leopard's Tale, Thames \& Hudson Ltd., London 2006, s.7-288.

James Mellaart, İngiliz Arkeolog. Ayrıntılı bilgi için bkz. https://en.wikipedia.org/wiki/James_Mellaart.

James Mellaart, The Neolitic Of The Near East, Thames And Hudson, London 1975, s.111-119.

Yeni Konya, 21 Mart 1961, s.2.
} 
gereken 5 milyon lira yıllık bütçede olmadığından onarımı yapılamayacaktır. Alâaddin Camiiyle ilgili olarak sadece küçük çaplı bir kubbe onarımı planlanmaktadır²8.

Şubat ayında onarımının yapılacağı duyurulan Konya Atatürk Anıtı ile ilgili yeni bir haber Nisan ayında basında görülmüş ve ilgili faaliyetin ihale sürecinin başladığı duyurulmuştur ${ }^{29}$. Aynı gün bir diğer gazetede ise Koyunoğlu Müzesinin sahibi konumundaki vatandaşa Maarif Bakanlığı tarafından bir mektup gönderildiği ve müzenin kamuya devredilmesi konusunda görüşmeler yapmak üzere ilgili kişinin Ankara'ya davet edildiği okurlara duyurulmuştur ${ }^{30}$.

Bu arada, 1961 yılı Nisan ayında Yeni Konya Gazetesinde başlayan turizm haberleri dizisi Mayıs ayının başlarına kadar devam etmiştir. Yayın sırasına göre konumuzu ilgilendiren haberlere göz atmamız gerekirse; konu ile ilgili ilk haber 16 Nisan tarihlidir. Turizm davası il çapında gelişecek başlıklı haberde, il bazında turizme dair yapılması planlanan işlerle ilgili gerçekleştirilen bir toplantıdan bahsedilmiştir. Günün turizmle ilgili bir diğer başlı̆g ise, Ilğm Kaplıcaları Civarı İmar Ediliyor şeklinde olup, Kaymakamlık ve Belediyenin ortaklaşa çabaları ile bahsi geçen alanın turist çekebilecek bir hale getirilmesi için çalışmaların başladığından söz edilmiştir ${ }^{31} 19$ Nisan tarihinde ise, gazete, sayfalarını Konya ve çevresini kapsamak kaydıyla turizmle ilgili söz söylemek isteyen okurlarına açmıştır. Turizm konusunda bir anket açıyoruz başlı̆̆ ile verilen haberle gazete yetkilileri, halkın görüşlerini beklediklerini ilan etmişlerdir ${ }^{32}$.

24 Nisan 1961 tarihinde, Alman Spandauer Volkslatt Gazetesinde görev yapan bir grup muhabir, turizmi geliştirme ve gezip gördükleri yerleri okurlarına duyurma amacıyla çıktıkları tur kapsamında İstanbul'dan sonra Konya'yı ziyaret etmişler ve beyanatlarında, "Konya'yı çok beğendiklerini, yine ziyarete geleceklerini ve okurlarına da tavsiye edeceklerini" söylemişlerdir ${ }^{33}$.

Meram Üzerinde Önemle Duruluyor başlığı ile verilen habere göre, 15 günde bir toplantılar yapan yetkililer Meram'da tarihi dokuyu ortaya çıkartmak ve turizmi geliştirmek amacıyla zihin jimnastiği yapmaktadırlar. Meram deresinin üzerine yapılması planlanan köprü, bu kapsamda ortaya çıkan ilk fikir olmuştur ${ }^{34}$.

Dönemin Şerafeddin Camii İmamı Ali Güneş, 9 Mayıs tarihinde yayınlanan köşe yazısında, tarihi eser ve vatan kavramı arasında ilişki kurarak sözlerine başlamış, tarihi eserlerin korunmasının bir milli borç olduğunu açıkladıktan sonra da, Konya turizminin gelişmesi için çeşitli alt başlıklara ayırdığı 7 maddelik bir yapılması gerekenler listesi çıkartmıştır. Oldukça doğru tespitleri olan Güneş'in makalesi bir hayli dikkat çekicidir ${ }^{35}$.

Konya Çumra'da devam etmekte olan Çatalhöyük kazısı, yerel basında haber olmaya devam etmiştir. Bu tip haberlerin ilk sayfada hemen manşetin altında yer alması ise bizlere o dönemde, kültür ve tarihe en azından kalem ehlinin verdiği önemi göstermektedir ${ }^{36}$.

3 Haziran 1961 tarihinde, Konya Turizm Bürosunu ziyaret eden dönemin Basın Yayın ve Turizm Bakanı Cihat Baban, Konya Turizm Bürosunun faaliyet ve personelinden

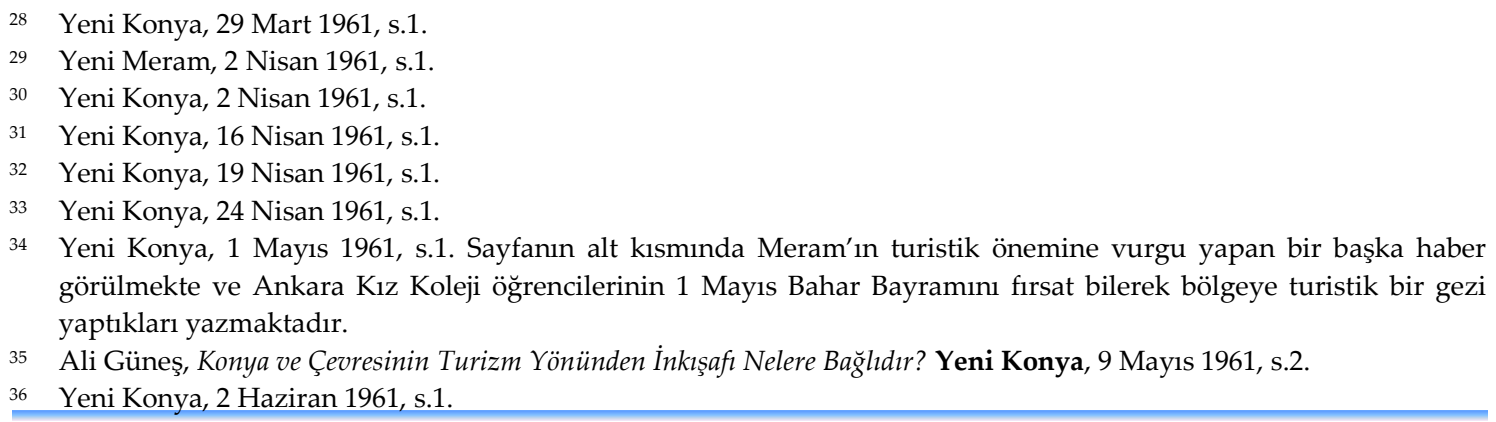

Yeni Konya, 1 Mayıs 1961, s.1. Sayfanın alt kısmında Meram'ın turistik önemine vurgu yapan bir başka haber görülmekte ve Ankara Kız Koleji öğrencilerinin 1 Mayıs Bahar Bayramını fırsat bilerek bölgeye turistik bir gezi yaptıkları yazmaktadır.

35 Ali Güneş, Konya ve Çevresinin Turizm Yönünden İnkışafı Nelere Bağlıdır? Yeni Konya, 9 May1s 1961, s.2.

36 Yeni Konya, 2 Haziran 1961, s.1. 
memnuniyetini dile getirmiş, turistlere kolaylık olması açısından, şehrin giriş ve çıkışlarına yeni tabelalar konulması ve kambiyo servisinin açılması talimatlarını vermiştir ${ }^{37}$.

12 Haziran 1961 tarihli Yeni Konya Gazetesinin ilk sayfasında, iki farklı turizm haberi, fotoğraflı ve çerçeveli, özel yazı karakterli şekli ile yer bulmuştur. Üst kısımda yer alan metinde; İvriz Hitit Anıtının turistik bir ziyaret yeri olarak tanıtılması amaciyla Basın Yayın ve Turizm Bakanlığınca bir broşür bastırılmaktadır. Alt kısımda ise, Konya Eski Eserleri Sevenler Derneği tarafından yakın bir gelecekte Şekerfuruş Mescidinin onarımına başlanacağı duyurulmaktadır ${ }^{38}$.

1961 yılında James Mellaart tarafından başlatılan Çatalhöyük kazılar1 ${ }^{39}$ devam ederken, Adil Gücüyener tarafından kaleme alınan ve manşetten verilen Sekizbin Ylllık Tarihi Bir Şehir Bulundu haberinin ilk kısmında; kazının başlangıç hikâyesi ve ilk günden haberin yazılış tarihine kadarki buluntular ayrıntılı bir şekilde anlatılmıştır. Konya Müze Müdürü ile kazı alanını görmeye giden Yeni Konya Gazetesi ekibi, Dr. Mellaart ve eşini de ziyaret etmiş ve gerçekleştirdikleri faaliyetler hakkında Bayan Mellaart'dan bilgi almışıı ${ }^{40}$. Bahsi geçen haberin yayınlanması üzerine Yeni Konya Gazetesine birçok telefon gelmiş, daha fazla bilgi isteyen kamuoyunun arzusu, ertesi gün yine Gücüyener tarafından hazırlanan ve Müze Müdürü Mehmet Önder'le ${ }^{41}$ Çatalhöyük hakkında yapılan bir röportajın yayını ile yerine getirilmeye çalışılmıştır. Kazı ve tarih hakkında açıklayıcı bilgiler veren müze müdürünün cümlelerinin sonunda, yakında Konya'ya yeni bir bilim heyetinin gelerek Çatalhöyük bölgesinde araştırmalar yapacağı ve bölgenin turizme kazandırılması için de çalışmaların başladığı bilgisi verilmiştir ${ }^{42}$.

Konya'da turizmi geliştirmeye yönelik pek çok faaliyetin görüldüğü 1961 yılında ele alınan bir diğer konu da, turistik mekânların bulunduğu ana caddelerin mümkün olduğunda yivli mozaik karesimon taşlar ile döşenmesi projesidir. Bu konu ile alakalı olarak Şerafettin Camiinin önünde çalışmanın başladığı basın aracılığı ile vatandaşlara duyurulmuştur ${ }^{43}$. Alaaddin Camii ve Sahip Ata Hamamının kalan son onarım işleri de ihale ile müteahhide verilmiştir ${ }^{44}$. Bu arada Konya Müzesi Müdürü Mehmet Önder, Kıbrıs'a bir Türk Müzesi açma görevi ile 15 günlük bir seyahate çıkmıştı ${ }^{45}$.

26 Haziran 1961 tarihi, Yeni Konya Gazetesinin ilk sayfasının neredeyse tamamı turizm konulu haberlere ayrılmıştır. 23 Haziran 1961 Cuma günü gerçekleştirilen ve Vali Rebii Karatekin'in de takip ettiği Konya Turizm Cemiyeti Yıllık Kongresinde, Konya turizmini geliştirmek için ne yapılmalıdır sorusuna çeşitli yanıtlar bulunmaya çalışılmıştır. En önemli gündem maddesi, her yıl 17 Aralık tarihinde yapılan Mevlana İhtifallerinin daha fazla katılım sağlanabilecek bir tarihe alınıp alınmaması konusu olmuş, tartışmaların ardından tarihin aynı kalması fikrinde anlaşılmıştır. Cemiyet, Konya'ya daha fazla insan çekmek için çeşitli fuarlar

37 Işık, 4 Haziran 1961, s.1.

38 Yeni Konya, 12 Haziran 1961, s.1.

39 BCA, f.030.18.01. y.159.19.9.

40 Yeni Konya, 14 Haziran 1961, s.1. Bayan Mellaart'ın Çatalhöyük kazısı hakkındaki açıklamasında, Konya'nın sosyo-ekonomik hayatına dair bazı veriler de bulunmaktadır. Yöre köylerinin zengin olduğu için çalıştıracak iş̧̧i bulamadıklarını ve başka bölgelerden getirttiklerinin altını çizen Mellaart, konakladıkları köyün misafirperverliğinden ise övgüyle söz etmiştir.

41 Mehmet Önder, Araştırmacı, yazar, şair, bürokrat. 1954-1964 yılları arasında Konya Müzeler Müdürlügü yapmıştır. Ayrıntılı bilgi için bkz. Önder, Mehmet, Konya Ansiklopedisi, C.7, Konya Büyükşehir Belediyesi Yayınları, Konya 2014, s.139-140. Ayrıca Mehmet Önder'in çalışmaları hakkında daha fazla bilgi için bkz. Mestan Karabacak, Konyalı Bir Folklor Araştırmacısı Dr. Mehmet Önder, Selçuk Üniversitesi Sosyal Bilimler Enstitüsü Basılmamış Yüksek Lisans Tezi, Konya 1993, s.1-162.

42 Yeni Konya, 15Haziran 1961, s.1.

43 Işık, 18 Haziran 1961, s.1.

44 Yeni Konya, 22 Haziran 1961, s.1.

45 Yeni Konya, 23 Haziran 1961, s.1. 
düzenlenmesi konularında çalışma yapma prensip kararını da bu toplantıda almıştır. Konya Turizm Davasında Hazırlıklı Değil başlığı ile verilen bir diğer haberde ise Ankara'da Basın Yayın ve Turizm Bakanı ile görüşen Konya Turizm Cemiyeti üyelerinden Fakih Özfakih, bakanın şahsı ve bakanlık personeli nezdinde Konya ve halkının turizm davasına hazırlıklı olmadıkları izlenimi olduğunu, üzülmenin değil, çalışmanın gerektiğini gazete aracılığı ile vatandaşlara duyurmuştur. Mevlana Müzesi Külliyesi Döner Sermaye ile İşletilecek başlıklı haberde ise verilen önergenin kabul edilmesi halinde, Mevlana müzesinin döner sermaye ile işleyen ve kendi kendine yeten bir kurumsal kimliğe kavuşacağ bilgisi verilmiştir ${ }^{46}$.

8 Temmuz 1961 tarihinde ise Konya basınında o yıl için biten Çatalhöyük kazısı ile alakalı olarak Dr.Mellaart'ın yöre halkına teşekkürü ve iyi dilekleri yayınlanmış ve kazının ilerleyen yıllarda devam edeceği duyurulmuştur ${ }^{47}$. 17 Temmuzda ise 1961 yılı içerisinde Beyşehir Eşrefoğlu Camii ve Karaman İbrahim Bey İmaretinin onarımlarına başlanacağı, gerekli bütçenin hükumet tarafından ayrıldığı haberi gazetelere yansımıştır ${ }^{48}$. Temmuz ayı içerisinde konumuz ile alakalı haberlerden bir diğeri; ilki 26 Temmuz günü denenecek olan ve Konya Belediyesince uygulamaya konulan bir tanıtım faaliyetidir. İstanbul-Adana hattında sefer yapan TCDD'na ait trenin Konya Garında 77 dakikalık rutin bekleme süresini göz önüne alarak düşünülen projede, belediye tarafından tahsis edilen bir otobüs isteyen yolcuları Konya Garından alacak, kent içerisinde belirli bir rota izledikten ve Mevlana Müzesi ziyaret edildikten sonra yolcular yine gara bırakılacaklardır. Rehberlik ve tercüme hizmetlerinin de verileceği bu faaliyet tamamen ücretsiz olacak ve Konya'nın tanıtımı amaciyla icra edilecektir. Bahsedilen bu haberin hemen altında, Müze Civarının Tanzimi İvedilikle Ele Alınıyor başlıklı ve Mevlana Müzesi fotoğraflı bir diğer haberde ise müze civarının düzenlenmesi işine ilgili bakanlığın öncülüğünde başlandığı ve çeşitli uzmanların gelerek incelemeler yaptığı bilgisi verilmiş, ardından da düzenleme işinde izlenecek yol haritası açıklanmıştır ${ }^{49}$.

1961 yılının, Ağustos ayında, Konya basınında pek çok tarihi eser, turizm vb. konulu haberler yayınlanmıştır. Bu haberlere göre; kentte bulunan Alaeddin Köşkü harabesi koruma amaçlı çelik bir kafese alınacak ve üzeri şemsiye gibi kapatılacaktır ${ }^{50}$. Aynı şekilde ahşap çatısı yıpranan Alâaddin Caminin de ilgili bölümü ahşap kısım yerinde kalmak kaydı ile mozaik betonla kaplanacak, bu iş için 23920 Lira ihale bedeli ödenecektir ${ }^{51}$. Beyşehir Eşrefoğlu Camii ile Akşehir Ulu Camii onarım ihaleleri tamamlanmış ve müteahhide verilmiştir ${ }^{52}$. Prof.Dr.Sedat Alp $^{53}$ tarafından 8 yıldır devam etmekte olan Konya Karahüyük kazılarına yakında yeniden başlanacak, ayrıca İngiliz Arkeoloji Enstitüsü Müdür Yardımcısı David Henry French ${ }^{54}$ tarafından da Karaman Canhasan Höyüğünde ${ }^{55}$ yeni bir kazı gerçekleştirilecektir ${ }^{56}$. İnşası devam eden yeni müze binası, 29 Ekim tarihine yetiştirilmeye çalışılacak ve Konya civarındaki kazılarda çıkarılan yeni eserler burada sergilenecektir ${ }^{57}$. Bu arada, 67885 Lira ihale bedeli olan

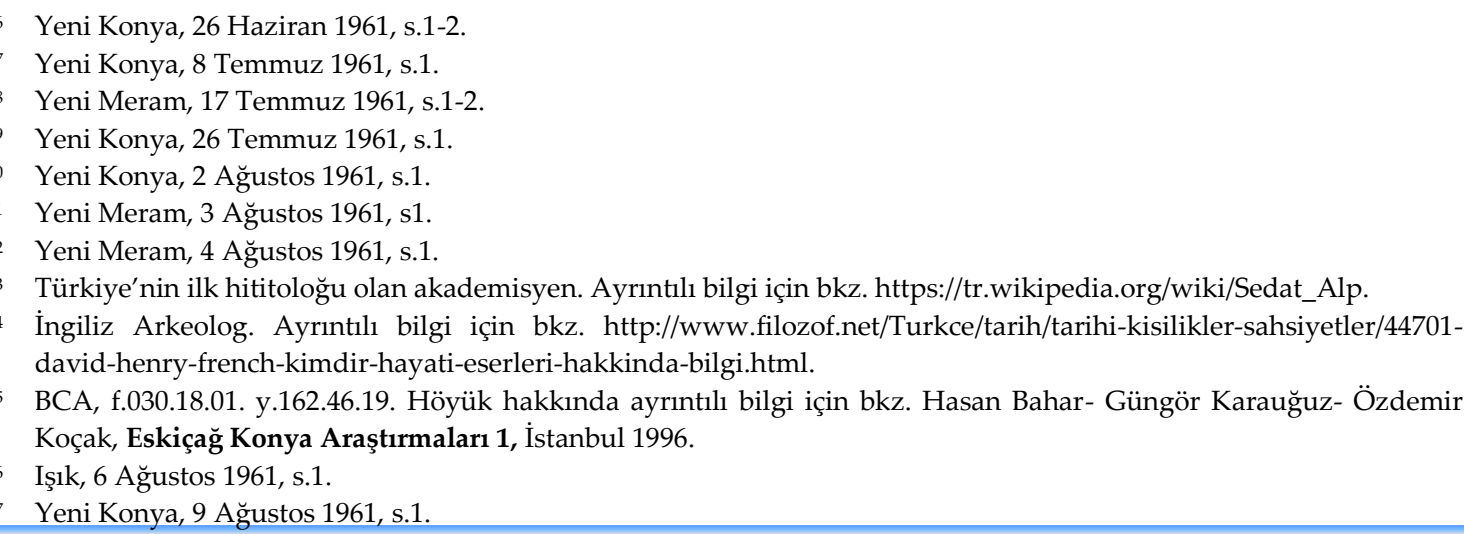


Sırçalı Mescit'in onarım ihalesinin \%28 kırımla müteahhide verildiği haberi de basında kendisine yer bulmuştur ${ }^{58}$.

Mevlana Caddesinin Tanzimine Başlanıyor başlığı ile sonbaharın ilk günlerinde verilen habere göre, Alâaddin Tepesinden Mevlana Müzesine giden caddede bir takım yenileme çalışmaları yapılacak, müzenin yanına inşa edilecek bir sebilde su ile birlikte turistler için kartpostal ve broşürler de bulundurulacaktır ${ }^{59}$. Eylül ayının ilk günlerinde Konya'yı ziyarete gelen Avusturya Ulaştırma Bakanı ve beraberindeki heyet, Konya'da gördükleri misafirperverlikten çok memnun kalmış ve kentten ayrılırken Vali Rebii Karatekin'e Avusturya Hükümetine ait seri pullardan oluşan bir albüm hediye etmişlerdir. Çok kıymetli bu hediyeyi Mevlana Müzesi Kitaplığına bağışlayan Rebii Karatekin, bir kez daha turizm ve tarihe verdiği önemi gözler önüne sermiştir ${ }^{60}$.

25 Eylül 1961 tarihinde Mehmet Önder, Meramda Onarılan Bir Eser adlı makalesinde, Meramda bulunan ve halk arasında Tekkebağı Mescidi olarak bilinen, asıl adı Cemel Ali Dede Mescit ve Türbesi olan müştemilatın, Konya ve Mülhakatı Eski Eserler Sevenler Derneğince onarıldığı haberini vermiş, eserin tarihi ve önemi hakkında açıklamalar yapmıştır61. Bu arada yine Meram'da, 2 milyon liraya mal olacak ve Selçuklu - Osmanlı eserlerinin sergileneceği bir Etnografya Müzesinin yapılacağ 1 haberleri yine aynı tarihlerde Konya basınına yansımıştır ${ }^{62}$.

Tarihi Eserlerimiz Aydınlatılacak başlığı ile verilen 1 Ekim tarihli habere göre, İstanbul'da incelemelerde bulunan Konya Belediye Başkan Yardımcısı Rıfat Öngay, Konya'da da turizmi geliştirmek amacıyla, özellikle tarihi eserlerin daha fazla aydınlatılması konusuna yoğunlaşacaklarını ve bunun için gerekli birimlere talimat verildiğini kamuoyuna duyurmuştur63.

Bu dönemde, Mehmet Önder, gazetelerdeki makaleleri ile Konya halkını tarih ve tarihi eser konularında bilinçlendirme çalışmalarına devam etmiş; Konya'da İlk Müze adlı makalesinde, Müze-i Hümâyun Konya Şubesinin kentte açılış hikâyesinden bahsetmiştir ${ }^{64}$.

Kasım 1961 tarihinde ise özel sektörün, sanat ve tarihe katkılarından bir örneğe Konya'da rastlanmaktadır. Kente şube açan Raybank ${ }^{65}$, açılış hatırası olarak Mevlana Müzesine kristal vitrinler yaptırma kararı almış ve bunun için 7000 Liralık bir destekte bulunmuştur ${ }^{66}$. Aynı ay içerisindeki bir başka haberde ise Milli Eğitim Bakanlığınca ${ }^{67}$ Konya Yeşil Türbe çinilerinin yenilenme ${ }^{68}$ konusu ele alınmaktadır ve kısa süre içerisinde bir ihale gerçekleştirilecektir ${ }^{69}$.

1961 yılı Mevlana İftihalleri için, Devlet Demiryolları, Konya'ya giden tren biletlerinde \%25 indirim yapmış, Konya Belediyesi ise özellikle Ankara'dan gelen günübirlik turistler için otobüs seferlerini $\operatorname{arttırmıştır~}^{70}$. Ayrıca Mevlana İhtifal Komitesinden 4 üye, Konya'nın turizm meselelerini görüşmek için, Basın Yayın ve Turizm Bakanından randevu alarak, Ankara'ya

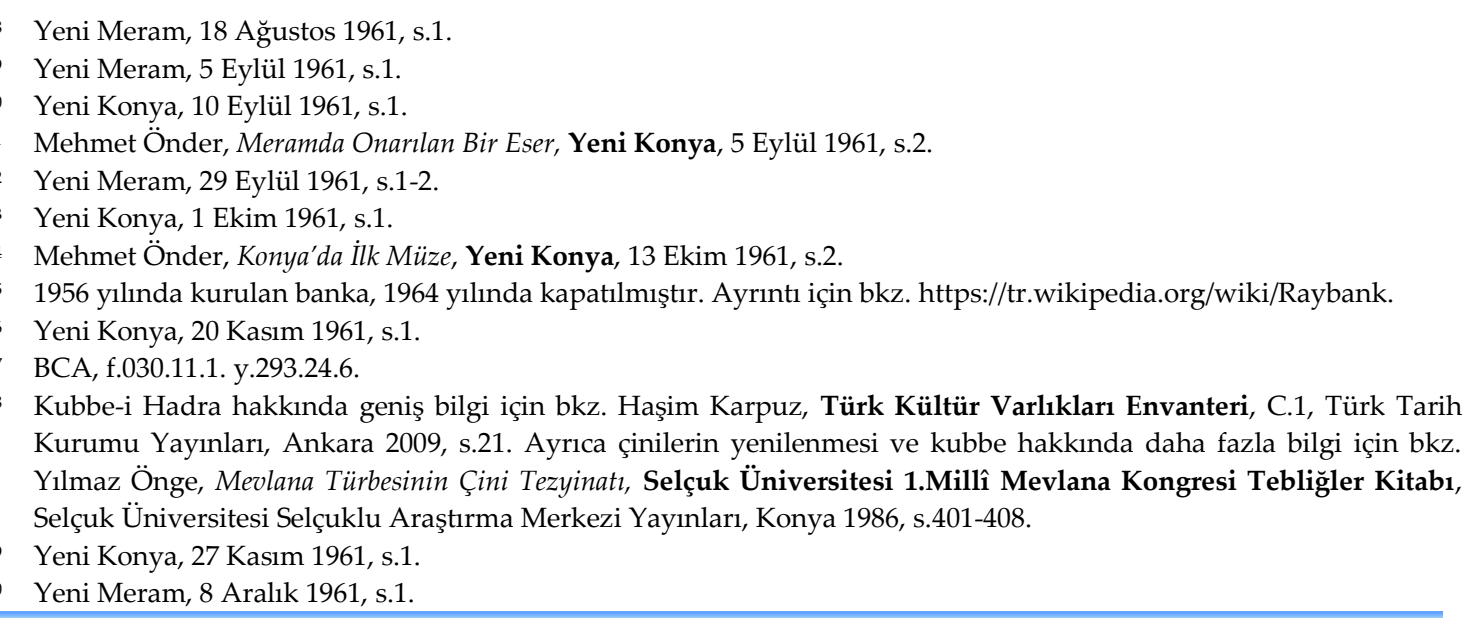


ziyarete gitmişlerdir ${ }^{71}$. Bu arada, M.Muhlis Koner tarafından hazırlanan Mesnevinin Özü adlı 6 ciltlik bir kitap Konya Belediyesince basılmış ve ihtifaller dolayısıyla dağıtımına başlanmıştır ${ }^{72}$.

Ankara'da bulunan Yüksek Anıtlar Kurulunda görevli 11 uzmanın, Konya'ya geleceği ve Sırçalı Mescit, Alaaddin Camii, Akşehir Ulu Camii, Karapınar ile Karaman ilçelerindeki tarihi eserlerin restorasyonu konularında incelemeler yapacağı bilgisi Konya yerel basınında haber olmuş ve kamuoyu aydınlatılmıştır ${ }^{73}$.

Yukarıda bahsi geçen Yeşil Türbenin Çinilerinin ihale hazırlığı tamamlandıktan sonra, 116 bin Lira bedelle müteahhit firmaya ihale edilmiş ve İstanbul'da üretilecek çinilerin en az 40-50 yıl dayanma garantisi alınmış ve kamuoyuna ilan edilmiştir ${ }^{74}$.

İplikçi Camiine Bir Çeşme Yaptırılacak başlığı ile verilen 1961 yılının çalışmamız ile alakalı son haberinde, tarihi İplikçi Camiinin arka kısmına, orijinalliğini bozmadan yeni bir şadırvan yapımına başlanacağı ve yine ihtiyaca binaen beton olan zeminin portatif ahşap döşeme ile yenilenmesinin Anıtlar Kurulunca onaylandığı bilgisi verilmiştir ${ }^{75}$.

\section{Yılında Konya'da Tarihi Eser ve Turizm Çalışmaları}

1962 yılının konumuz ile alakalı ilk haberi, Konya Müzelerinin 1961 yılı faaliyetlerini içeren; 1961 Yılında Müze Çalı̧̧maları başlıklı olandır. Yıl içerisinde müzelerdeki tüm faaliyetlerin dökümünün yapıldığı metinde öne çıkan bilgi, 241.814 ziyaretçinin müzeleri gezdiği ve 689 tarihi eser ve 325 el yazmasının envantere kaydedildiğidir ${ }^{76}$. Bu arada Tokat da bulunan, üçüncü en eski Mesnevi nüshası satın alınarak Mevlana Müzesine getirilmiştir ${ }^{77}$.

Şubat ayının başlarında Konya'da incelemelerde bulunan fuarcılık konusunda uzman bir heyet, Konya'nın coğrafi yapısı ve tarihi eserleri göz önüne alındığında büyük bir turizm potansiyeline sahip olduğunu fakat turistlerin konaklaması için yeterli tesisin bulunmadığını, hediyelik eşya satan mağazaların daha düzgün olması ve kaliteli ürün satması gerektiğini belirtmiştir. Bu haberin verildiği gün, basına yansıyan bir başka güzel olay ise İstanbul'da yaşayan Hulusi Gökmen ve Cahit Gözkan adlı işadamlarının Mevlana Müzesinde kullanılmak üzere otomatik bir merdiven bağışlamalarıdır ${ }^{78}$.

Türkiye'de müzeleri en çok ziyaret edilen şehir: Konya başlığı ile verilen haberdeki bilgiye göre, 1961 yılında Konya'daki müzeleri ziyaret eden turist sayısı 22 bindir. 1962 yılında bunun 50 binin üzerine çıkması için çalışmalar yapılmaktadır ${ }^{79}$.

Mart 1962 itibarı ile Konya Eski Eserleri Sevenler Derneğinin yıllık planı açıklanmış ve 6 tarihi eserin onarımı tasarlanmıştır. Planlamada Tacülvezir Türbesi ilk sırayı almaktadır ${ }^{80} .13$ Mart tarihinde ise Senatör Kamil Karavelioğlu, Mevlana Müzesini ziyaret etmiş ve tespit edilen eksikliklerin giderilmesi için notlar almıştır ${ }^{81}$.

Müzeler Konseyinin (ICOM) Konya'daki Açık Oturumu başlıklı haberde, Ankara'daki ICOM Toplantısından Konya'ya gelen bir heyetin müzecilik konusunda düzenlediği ve başta Vali Rebii Karatekin olmak üzere şehrin ileri gelenlerinin katıldığı açık oturum ve alınan kararlar hakkında bilgi verilmiş, Konya'nın yeni müzelere ihtiyacı olduğu tespit ve vurgusu

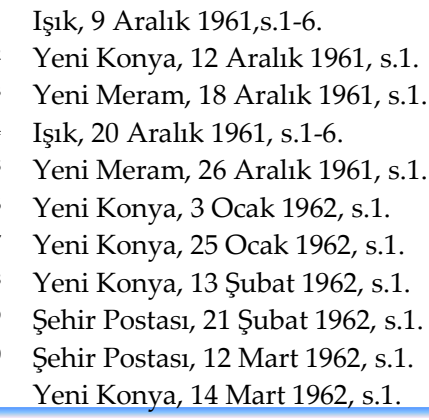


yapılmıştır ${ }^{82}$. Konya Müze Müdürü Mehmet Önder, yaptığı açılamada; Koyunoğlu Müzesinin Etnografya ve İslam Sanatları Müzesine dönüştürülmesi gerektiğini, Basın Müzesi kurulması çalışmalarının tamamlanmak üzere olduğu, Devrim ve Açık Hava Müzesi konularında da çalışmalar yapıldığını söylemiştir ${ }^{83}$.

28 Mart 1962 tarihinde Konya basınında, Vakıflar Müdürlüğünün gelecek aylardaki restorasyon programı açıklanmış ve ihale bedelleri kamuoyuna duyurulmuştur. Bitişikte, Hitit Anıtları Korunuyor başlığı ve anıtın büyük bir fotoğrafı ile verilen haberde ise, İvriz Anıtının korunma ve turizme kazandırılma çalışmalarına başlandığını bilgisi ile birlikte anıtın kısa tarihçesi de verilmiştir ${ }^{84}$.

Daha önce Sivas Valisi iken başarılı çalışmaları neticesinde, 12 Ocak 1950 tarihli Bakanlar Kurulu Kararıyla takdirname ile taltif edilen ${ }^{85}$ Rebii Karatekin, 29 Mart 1962 tarihli Bakanlar Kurulu Kararıyla; "Eski eserlere, tarihi kıymetlere ve müzelere karşı gösterdiği yakın ilgi dolayısıyla", yeniden takdirname almaya hak kazanmıştır ${ }^{86}$.

Konya'da açılması planlanan Devrim Müzesi ile ilgili haberlere bir yenisi daha eklenmiş ve Atatürk'ün Konya ziyaretlerinde kullandığı, Konyalılarca kendisine hediye edilmiş ve vali konağ1 olarak hizmet veren evin, Atatürk ve Türk Devrim Tarihi Müzesine dönüştürüleceği bilgisinin alındığı ve şehirde sevinç uyandırdığı kamuoyuna arz edilmiştir ${ }^{87}$. Sofu Tuğrul, gazetedeki makalesinde, Atatürk'ün Konya ve Konyalılara olan düşkünlüğü ve açılacak devrim müzesinin ne kadar önemli olduğundan bahsetmiş ve projeye destek vermiştir88.

Kültür Merkezleri İçinde Konya'nın Yeri başlığı ile verilen habere göre; Milli Eğitim Bakanlığı, Konya Valiliğine gönderdiği bir yazıda, kentte bir sanat galerisi ile sanat atölyesi kurmak istediğini, Konya sanat, tarih ve kültürüne katkı yapacak bu projenin tüm uzman personel ihtiyacının da bakanlıkça karşılanacağını bildirmiştir ${ }^{89}$. İlgili projenin nerede açılması konusunda toplanan Konya bürokratları; Torrance Gazinosunun binasını bu iş için uygun bulmuşlardır ${ }^{90}$.

Eski Eserlerin Onarımı İçin 5 Yıllık Program başlığı ile manşetten verilen habere göre, Vakıflar Genel Müdürlüğü, Konya'daki tarihi eserlerin onarımı için 5 yıllık bir plan hazırlamış ve proje kapsamında Yüksek Mimar Ali Sami Ülgen'in başkanlığında bir heyet kentte incelemeler yapmışır. Yakında farklı uzmanlık alanlarından heyetler Konya'ya gelmeye devam edecek ve bu arada hala tescillenmemiş bazı tarihi eserlerin de tescil işlemi gerçekleştirilecektir ${ }^{91}$.

27 Nisan 1962 tarihinde Konya basınında çalışmamız ile alakalı yayınlanan haberlerden öğrendiğimize göre; 120 kişilik bir Alman turist grubu kendi otobüsleri ile kente gelmiş ve başta Mevlana Müzesi olmak üzere tarihi ve turistik yerleri ziyaret etmişlerdir ${ }^{92} .120$ kişilik turist kafilesinin kente gelişinin ilk sayfada haber olarak yer alması, dönemin Konya kamuoyunun turizme bakışını değerlendirmek açısından da oldukça önemlidir. Günün bir diğer haberi ise çeşitli nedenlerle kamu ve özel işletmelere geçmiş bulunan tarihi eserlerle ilgili çıan yeni kanun gereğince, Konya'da, Vakıflar Genel Müdürlüğüne devredilecek tarihi eserlerin adlarının

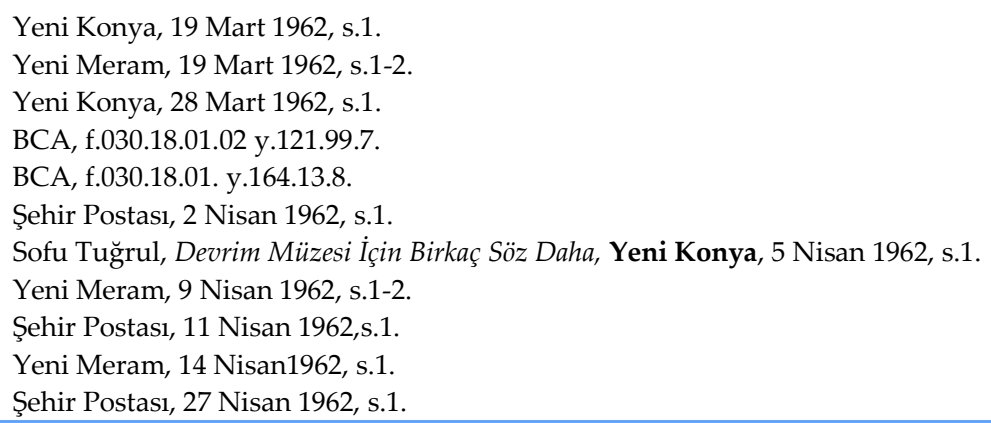


zikredildiği metindir. Buna göre: Horozlu Han, Zazadın Han, Raziye Hatun Kervansarayı, Eşrefoğlu Külliyesi ve Atlas Han Vakıflara devredilecektir ${ }^{93}$.

Bu arada, Mevlana ile Şems-i Tebrizî'nin ilk buluştukları yere bir anıt dikilmesi projesi ilk defa 12 Mayıs 1962 tarihli Konya basınında haber olarak görülmüştür ${ }^{94}$. Mayıs ayında Konya'daki tarihi eserler ve turizmle ilgili diğer sevindirici haberler şu şekildedir: Cumhuriyet Gazetesi Eski Yazı İşleri Müdürü Kemal Salih Sel, şahsi koleksiyonundan 73 ciltlik ve bir kısmı eski yazılı, Cumhuriyet ve Yeni Sabah nüshalarını Mevlana Müzesine bağışlamıştır ${ }^{95}$. Akviran Nahiyesi Kavaklı Köyünde, 100-150 metre büyüklügünde ve içi sanat eserleri ile dolu bir mağara keşfedilmiştiri ${ }^{96}$ İ́likçi Caminin arka kısmındaki İhata duvarı tamamlanmış, şadırvan inşaatına başlanmıştır ${ }^{97}$.

Konya müzelerine halkın yaptığı bağışların ilk sayfadan haber olma geleneği 1962 Haziranında da devam etmiş, Murat Özönler adlı öğretmenin 6 bin yıllık neolitik bir toprak testiyi müzeye bağışladığı kamuoyuna duyurulmuştur ${ }^{98}$. James Mellaart'ın yürüttüğü Çatalhöyük kazısı ise yazın gelmesi ile birlikte yeniden başlamıştır ${ }^{99}$.

UNESCO Milli Komitesinin Ankara veya İstanbul'da her ay gerçekleştirdiği mutat toplantısı, 17 Haziran 1962 tarihinde ilk defa Konya'da düzenlenmiş; bilim, eğitim ve kültür alanında çeşitli faaliyetler yürütülmüştür ${ }^{100}$. UNESCO Milli Komitesinin, Konya'da bir toplantı yapması, o dönemde Konya'nın ne denli önemsendiğinin bir göstergesidir.

Tarihi K.Karatay Restore Ediliyor başlı̆g 1 ile verilen haberde, Karatay Medresesi karşısında bulunan Küçük Karatay olarak anılan tarihi eserin restore planlarının hazırlandığı bilgisi Konya kamuoyu ile paylaşılmıştır. Aynı günkü gazetede ayrıca, Ilgın Lala Mustafa Paşa Camii, Karaman Ulu Camii, Hatuniye Medresesi ve İbrahim Bey İmaretinin restorasyonu için gereken paranın hazineden geldiği ve yakında ihale sürecinin başlayacağı bilgisi verilmiştiri101.

Temmuz ayında ihalesi yapılması planlanan Sultan Alaeddin Türbesi ile Sırçalı Mescidin onarımı ve ihale süreci hakkında ön bilgi 30 Haziran 1962 tarihinde Konya basınına yansımıştı1 ${ }^{102}$. Aynı gün, manşetten verilen bir başka haber Konya ile alakalı olmamakla birlikte, dönemin Konya basınının tarihi eser bilincini anlatması açısından önemlidir. Mısır piramitleri fotoğrafı ile verilen haberde güney batı Anadolu'da Amerikalı arkeologlarca gerçekleştirilen kazılar hakkında bilgi verilmektedir ${ }^{103}$.

Konya Müze Müdürü Mehmet Önder, fırsat buldukça yazıları ile Konya halkını tarih ve tarihi eserler hakkında bilgilendirmeye devam etmiş ve Eski Eserlerimiz başlıklı makalesinde, Konya'yı ziyaret etmiş bazı yabancıların yazılarından alıntılar yaparak tarihi eser- medeniyet kavramı arasında ilgi kurmuş, eserlerimizi daha iyi korumamız için yapılması gerekenlerden bahsetmiştir ${ }^{104}$. Mehmet Önder'in yazısından 2 gün sonra ise, Cihanbeyli İlçesi Oğuzeli Köyünde camii inşaatı sırasında Oğuz Türklerine ait büyük bir tarihi odanın bulunduğu haberi

Yeni Konya, 27 Nisan 1962, s.1-2.

Şehir Postası, 12 Mayıs 1962, s.1.

Şehir Postası, 21 Mayıs 1962, s.1.

Yeni Konya, 27 Mayis 1962, s.1.

Yeni Meram, 30 Mayıs 1962, s.1.

98 Yeni Konya, 7 Haziran 1962, s.1.

9 Yeni Konya, 8 Haziran 1962, s.1.

100 Şehir Postası, 18 Haziran 1962, s.1-3.

101 Yeni Konya, 26 Haziran 1962, s.1.

102 Yeni Meram, 30 Haziran 1962, s.1.

103 Şehir Postası, 30 Haziran 1962, s.1.

104 Mehmet Önder, Eski Eserlerimiz, Yeni Konya, 12 Temmuz 1962, s.2-3. 
basına yansımıştır ${ }^{105}$. Birkaç gün sonra ise Ereğli Rüstem Paşa Bedesteninin onarım işinin başladığı bilgisi kamuoyuna duyurulmuştur ${ }^{106}$.

Temmuz ayının son haberleri ise, Alâaddin Keykubad Köşkü üzerine koruma amaçlı yapımı devam eden örtü hakkında verilen bilgidir. Buna göre, ilki Roma'da görülen bu sistem, ikinci olarak Konya'da uygulanmaktadır. Manşetten verilen bu haberin alt kısmında, Konya Turizm Cemiyeti Enformasyon Bürosu Kuruluyor başlıklı metinde, büro kurulması için gerçekleştirilen çabalardan bahsedilmekte ve devamında, turizm rehber yenileme kurslarının yakında başlanacağ 1 yazmaktadır ${ }^{107}$.

1 Ağustos 1962 tarihli Şehir Postası gazetesinin haberine göre ise kent merkezine yapılması planlanan kültür parka, Koyunoğlu Müzesi taşınacak ve ziyaretçi sayısında artış sağlanmaya çalışılacaktır ${ }^{108}$. Ertesi günkü Yeni Konya gazetesinde Karahüyük Hafriyatına Bu Yıl da Devam Ediliyor başlığı ile ilk sayfadan verilen haberde, Prof.Dr.Sedat Alp tarafından 8 yıldır devam etmekte olan kazıda M.Ö.3000 yılına tarihlenen ve bugüne kadar bulunan en büyük kentten bahsedilmiş ve kazı hakkında ayrıntılı bilgiler sunulmuştur ${ }^{109}$.

Eski Klasik Türk Halları Dokunuyor Akviran'da adlı makalesinde, Konya'nın Akviran kasabasında eski okul binasının, yöre kadınlarının hizmetine tahsis edilmesi ve burada eski Türk sanatına uygun halıların dokunmaya başlamasının hikayesini, 6 Ağustos 1962 tarihinde okurlarına aktaran kişi, Durmuş Küçük'tür ${ }^{110}$.

Vilayetimizde tarihi eserlerin tamirleri manşet haberinde, hali hazırda Konya il sınırları içerisinde devam eden çalışmalar ile takvimi belirlenen eserler ve tasarı aşamasında olanlar hakkında ayrıntılı bilgi verilmiştir ${ }^{111}$. Aynı şekildeki haberler ertesi gün de Konya basınında yer bulmuş ve Karaman'da ihata duvarları tamamlanan çeşitli eserlerin listesi ile Konya merkezde minaresine paratoner takılan Sultan Selim Camii hakkında bilgiler aktarılmıştır ${ }^{112}$. Bu bilgilerin akabinde, İmar İskân Bakanlığı Devlet Planlama Dairesi tarafından sorulan soruya binaen, Konya Belediyesince, Mevlana Külliyesinin geliştirilmesi için gereken tüm hizmetlerde kullanılmak üzere, 1963 yılı için 5.721 .400 Lira bütçe talep edilmiştir ${ }^{113}$.

Konya okurunu tarih ve tarihi eserler konusunda bilgilendirme konusunu kendisine misyon edinen dönemin müze müdürü Mehmet Önder, 14 Ağustos 1962 tarihinde Çatalhüyük Kazıları Üzerine başlıklı makalesinde, 2 yıldır devam eden kazı, buluntular ve medeniyet üzerine doyurucu bilgiler vermiş ve tüm yöre halkını bir kez olsun kazı alanını ziyaret etmeye davet etmiştir ${ }^{114}$. Birkaç gün sonra ise dönemin Konya basınının önemli kalemlerinden Selçuk Es, Ladik ve Sızma bölgesindeki Roma döneminden kalan civa madenleri ve mağaraları konusunda ilginç bilgiler veren bir makale yayınlamış ve hem okurlarını tarihi bir mevzuda bilgilendirmiş hem de ilgili eserlerin korunması yönünde bir farkındalık oluşturmaya çalışmışırı1 ${ }^{115}$.

22 Ağustos 1962 tarihinde, Konya'da tüm yerel basinın üzerinde önemle durduğu ve Yeni Konya gazetesinin manşetten büyük fotoğraflar ile verdiği habere göre; 30 Ağustos tarihinde

05 Yeni Konya, 14 Temmuz 1962, s.1.

106 Yeni Meram, 26 Temmuz 1962, s.1-2.

107 Şehir Postası, 31 Temmuz 1962, s.1.

108 Şehir Postası, 1 Ağustos 1962, s.1-3.

109 Yeni Konya, 2 Ağustos 1962, s.1-3.

110 Durmuş Küçük, Eski Klasik Türk Halıları Dokunuyor Akviran'da, Şehir Postası, 6 Ağustos 1962, s.1-3.

111 Yeni Meram, 9 Ağustos 1962, s.1.

112 Şehir Postası, 10 Ağustos 1962, s.1.

113 Yeni Meram, 11 Ağustos 1962, s.1-2.

114 Mehmet Önder, Çatalhüyük Kazıları Üzerine, Yeni Konya, 14 Ağustos 1962, s.2.

115 Selçuk Es, Konya ve Civarındaki Civa Madenleri ve Romalılardan Kalan Mă̆aralar, Şehir Postası, 21 Ağustos 1962, s.1. 
yapımı tamamlanan Modern, Klasik Eserler Müzesi açılacaktır ve yeni müzenin yılda 50 bin kişi tarafından ziyaret edilmesi beklenmektedir ${ }^{116}$. Yeni müzenin açılacağı bilgisi, 30 Ağustosta daha küçük bir haber olarak verilmiş117, 31 Ağustosta ise tüm tafsilatı kamuoyu ile paylaşılmıştır118.

Sonbaharla birlikte, İngiltere hükumetinin kültür faaliyetleri için, Türkiye'den davet ettiği 4 vali arasında Konya Valisi Rebii Karatekin'de vardır ve 28 Ekimde başlayacak 14 günlük kültür seyahati, kent basınında ilk kez 4 Eylül 1962 tarihinde kendisine yer bulmuştur ${ }^{119}$.

Yeni yılın yaklaşması ile birlikte, Konya basınında, 1963 yılı tarihi eser onarım planları hakkında haberler çıkmaya başlamıştır. Vakıflar Genel Müdürlüğünün, Bulgur Tekkesi Camii hakkında ekspertiz çalışmalarına başladığı, uzun süredir ele alınamayan ve yer yer yıpranmaların oluştuğu Sahip Ata Külliyesinin 1963 yılında açık hava müzesine dönüştürülme planlarının yapıldığı ve Seydişehir Seydiharun Caminin, 18-20 bin lira tutarındaki onarım masraflarının Mehmet Bey isimli bir hayırseverce üstlenildiği bilgileri kamuoyu ile paylaşılmıştır ${ }^{120}$. Bu arada Bozkır İlçesinde bulunan eski bir Bizans kilise harabesinde, 16 adet tablo ve bir el yazması İncil bulunmuştur. 1000 yıllık olduğu saptanan tablolar ile ilk sayfaları yıpranmış olan İncil korumaya alınarak Konya'ya getirilmiştirir2. Yaklaşık aynı tarihlerde, Konya'da açılması planlanan Basın ve Kültür Müzesinde sergilenmek üzere 1867 tarihli Alman malı litograf cihazı (taş basma tezgahı) Konya Lisesi deposundan alınarak müzeye nakledilmiştir. Konya'da yayınlanmış olan geriye dönük 100 yıllık dergi ve gazetelerin ilk nüshaları ve tüm koleksiyonlarını tamamlama çalışmaları ise devam etmektedir ${ }^{122}$. Aynı günlerde Konya'yı ziyaret eden UNESCO temsilcileri, Mevlana müzesinden ayrılmak istememiş, programın sıkışıklı̆̆ından şikâyet ederek; Konya'nın birkaç günde gezilmesinin mümkün olmadığı, kentin eşsiz bir tarihi hazine olduğunu belirtmişlerdir ${ }^{123}$.

1963 yılı faaliyet planlarının açıklanmasına Ekim ayında da devam edilmiştir. Basındaki haberlere göre: Alaaddin Camine 1962 yılında 45 bin lira harcanmış ve 1963 yılı içinse 150 bin lira ödenek ayrılmıştır. İplikçi Camiinde ise şadırvanın yenilenmesi, hasar görmüş çeşitli kısımların onarılması işleri Müze Müdürlüğü ile Vakıflar Genel Müdürlüğü arasında paylaştırılmıştır. Minarenin tamir masrafları ise İşadamı Mehmet Karacığanlı tarafından üstlenilmiştir ${ }^{124}$. Bu arada, Karapınar'da bulunan ve II. Selim zamanında yapılan Yavuz Selim Camiinin korunması için, Kaymakam ve Belediye Başkanı Sedrettin Sürbahan tarafından bahçe duvarları yenilenmiş ve kullanıma açılmıştır ${ }^{125}$. Yaklaşık aynı tarihlerde Sultan Selim Caminin eksik kısımlarının kurşun kaplamalarının yenilenmesi işi ihaleye çıarılmış ve 45 bin lira bedelle müteahhide verilmiştir ${ }^{126}$.

Akşehir ilçesi, Apsarı köyünde bulunan bir höyükte yapılan kazılar sonucunda, Roma ve Bizans dönemine ait çeşitli heykeller, sütun ve mimari kalıntıları ortaya çıkarılmış ve uzmanların incelemesine sunulmuştur ${ }^{127}$. Ertesi günkü gazetelerde ise Temelhisar Kasabasında Jüpiter Mabedine ithafen yapılmış bir havuzun arkeologlarca bulunup restore edildiği ve ziyarete açıldığı bilgisi verilmiştir ${ }^{128}$. Bir gün sonra ise Konya basınında konumuz ile alakalı

\footnotetext{
Yeni Konya, 22 Ağustos 1962, s.1.

Şehir Postası, 30 Ağustos 1962, s.1.

Yeni Konya, 31 Ağustos 1962, s.1.

9 Yeni Konya, 4 Eylül 1962, s.1.

120 Yeni Konya, 8 Eylül 1962, s.1-4.

121 Yeni Meram, 10 Eylül 1962, s.1.

122 Yeni Konya, 14 Eylül 1962, s.1.

23 Şehir Postası, 17 Eylül 1962, s.1.

124 Yeni Meram, 1 Ekim 1962, s.1.

125 Şehir Postası, 8 Ekim 1962, s.1.

126 Yeni Konya, 19 Ekim 1962, s.1.

127 Yeni Konya, 22 Ekim 1962, s.1.

128 Şehir Postasi, 23 Ekim 1962, s.1.
} 
Tarihi Kervansaray Onarllıyor başlığı ile verilen habere göre; Ilgın'da bulunan tarihi kervansaray Vakıflar Genel Müdürlügünce restore edilmeye başlanmıştır ve muhtemelen kapalı çarşı şeklinde halkın hizmetine sunulacaktır ${ }^{129}$.

Dönemin Konya'sında sadece il merkezi değil, ilçelerde de müze ve müzecilik fikri ön plana çıkmıştır. Yerel basında, 27 Ekim 1962 tarihli bir haberde, Karapınar ilçesinde Arkeoloji müzesi açılacağı kamuoyuna duyurulmuş ve bunun ilçe halkında sevinç uyandırdığı bilgisi paylaşılmıştır ${ }^{130}$. Konyalıların müzelere olan ilgisini gösteren bir başka haber ise 29 Ekim Cumhuriyet Bayramı tatili dolayısıyla kent müzelerine halkın gösterdiği ilgidir. 3 gün içerisinde sadece Mevlana müzesini 3600 vatandaş ziyaret etmiştir ${ }^{131}$.

29 Mart 1962 tarihinde, eski eserler, tarihi klymetler ve müzelere gösterdiği ilgi neticesinde takdirname ile ödüllendirilen Konya Valisi Rebii Karatekin, 11 Ekim 1962 tarihli Bakanlar Kurulu Kararıyla, bu kez; "Milli Eğitim meselelerine gösterdiği ilgi, okul yapımı ve onarımındaki büyük gayret ve başarısından dolayı" yeni bir takdirname ile taltif edilmiştir ${ }^{132}$.

1963 yılı yaklaştıkça, tarihi eserler ile ilgili faaliyet planları da netleşmeye, yenilenmeye ve halka aktarılmaya devam etmiştir. Bu minval üzere, Sultan Selim Caminin yenileneceği duyurusu tekrarlanmış ${ }^{133}$, Alaaddin Caminin restorasyonunda daha önce belirtilen konular dışında toprak olan damının bakır kaplama ile değiştirilme kararı ve 1.5 milyon liralık ödeneği konusunda da bilgilendirme yapılmıştır ${ }^{134}$. Yıl boyunca tamiri gerçekleşecek tarihi camiler: Bulgur Tekke Cami, Hoca Hasan Cami, Karapınar Selimiye Cami ve imareti135, Sahip Ata Cami ve külliyesi, Akşehir İmaret Cami, Taş Medrese, Karaman Tecvidi Karabaş Cami şeklinde açıklanmıştır ${ }^{136}$.

28 Kasım 1962 tarihinde ise Konya Turizm Derneği; ileride kurulması planlanan Mevlana Enstitüsünün ilk nüvesi olmak üzere, Mevlana Armă̆anı adlı bir bilim ve sanat eseri projesinin duyurusunu yapmıştır. 1963 Mevlana haftasında sonlanacak projenin galibine 5 bin lira para ödülü verilecektir ${ }^{137}$.

1962 yılı Mevlana İhtifalleri 8 Aralık tarihinde başlamış ve basında manşetten yer bulmuştur. Çeşitli bakanlar ve milletvekillerinin katılımının beklendiği törenlere; Ankara Valisi ile $A B D$ ve Brezilya Büyükelçileri de katılacaklar arasında sayılmıştır ${ }^{138}$. 17 Aralık tarihinde 14 . ve son seansla kapanan kutlamaların önceki yıllara göre çok daha görkemli geçtĭgi basına yansımıştır ${ }^{139}$.

\footnotetext{
Yeni Konya, 24 Ekim 1962, s.1.

Şehir Postası, 27 Ekim 1962, s.1.

Yeni Konya, 31 Ekim 1962, s.1.

BCA, f.030.18.01. y.166.47.8.

Yeni Meram, 6 Kasım 1962, s.1.

34 Yeni Meram, 7 Kasim 1962, s.1.

135 Yeni Meram, 13Kasim 1962, s.1.

136 Yeni Meram, 20Kasim 1962, s.1.

137 Yeni Konya, 28 Kasım 1962, s.1.

138 Şehir Postası, 8 Aralık 1962, s.1. İlerleyen günlerde listeye eklenen isimler şu şekildedir: Başbakan Yardımcısı Hasan Dinçer, İmar ve İskân Bakanı Fahrettin Kerim Gökay, Basın Yayın ve Turizm Bakanı Celal Tevfik Karasapan, Cumhuriyet Senatosu Başkanı Suat Hayri Ürgüplü, Mevhibe İnönü ve kızı Özden Toker, CENTO'da görevli 10 kişi, İsrail, Hollanda ve Afganistan Büyükelçileri. Ayrıntı için bkz. Şehir Postası, 13 Aralık 1962, s.1.

139 Son seansa Bayırdıklık Bakanı İlyas Seçkin, Adalet Bakanı Abdulhak Kemal Yörük, Devlet Bakanı Rauf Aybar ile çeşitli milletvekilleri ve senatörler katılmıştır. Orta ve yüksekokul öğrencileri arasında Hz. Mevlana ve Konya Turizmi konulu kompozisyon yarışmaları düzenlenmiş ve ilk üçe girenlere 300'er liralık armağanlar verilmiştir. Şehir Postası, 18 Aralık 1962, s.1.
} 


\section{Yılında Konya'da Tarihi Eser ve Turizm Çalışmaları}

1963 yılında Konya yerel basınında çalışmamızla alakalı ilk haber; Koyunoğlu Müzesine Ordu ve Bankalar Geniş Çapta Yardım Ettiler başlığı ile verilmiştir. Haberin tafsilatında Ordu Komutanı Cemal Tural'ın emriyle askeri teknisyenlerin uzun süre çalışarak müzenin elektrik tesisatını yenilediği ve yangına karşı korumalı hale getirdiği ile çeşitli banka ve firmaların birer kristal vitrin yaptırarak müzenin teşhir kalitesini arttırdığından bahsedilmekte, bunun Konya turizmine olan katkısı anlatılmaktadır ${ }^{140}$.

Karapınar ilçesi Sultan Selim Cami ile ilgili, ilçe kaymakamının öncülüğünde yürütülen düzenleme çalışmaları, Şubat ayında da Konya basınına yansımış ve caminin duvar ve bahçe düzenlemesinin yanı sıra etrafındaki kötü görüntüye sebep olan unsurların temizlenmesi aşamasına geçildiği bilgisi kamuoyu ile paylaşılmıştır ${ }^{141}$. Her dönemde olduğu gibi olumlu çabalara karşı, zaman zaman görülen olumsuz hareketlerden birisi olarak, Sultan Selim Caminin kurşun kısımlarının çalınma hadisesi yerel basına yansımış fakat Konya'nın çeşitli semtlerinden olan hırsızlar kısa sürede yakalanmışlardır ${ }^{142}$. Hırsızlık haberinden kısa süre sonra İplikçi Şadırvanı Tamamlandı başlığı ile verilen güzel haberde, İplikçi Caminin 90 bin liraya mal olan yeni şadırvanının inşaatının bittiği, 2 güne kadar su tesisatının da açılmasıyla halkın hizmetine açılacağı bilgisi verilmiştir ${ }^{143}$.

5 Mart 1963 tarihinde Devlet Bakanı Ali Şakir Ağanoğlu başkanlığında, Vakıflar İdaresi Genel Müdürü Nihat Danışman'ın da içinde olduğu kalabalık bir heyet Konya'ya gelmiş ve 1963 yılında tamir edilmesi planlanan tarihi eserleri ziyaret etmişlerdir. Tetkik gezisi sırasında bakan Ağanoğlu; Konya'daki eserleri tamiri için 1 milyon liralık bir bütçe ayrıldığını ve ihalelerin Mayıs ayında başlayacağını açıklamışııı' ${ }^{144}$.

Şehir Postası Gazetesinin, isimsiz olarak yayınlanan Olayların İçinden köşesinin, 9 Mart 1963 tarihli konusu; Türkiye'nin Arkeolojik Hazinesi başlı̆̆ı ile verilen ve Türkiye'de bulunan tarihi eserlerin önemi, dünyanın bunlara ilgisi ve korunma yollarının anlatılması olmuştur ${ }^{145}$. Bu arada yerel basına, sadece tarihi eserler ile ilgili yapılan olumlu faaliyetler ve bilgilendirmeler değil, zaman zaman çeşitli şikâyetler de yansımıştır. Sahip Ata Külliyesi ve Klasik Müzenin önünde kıştan kalan çamur ve moloz yığınlarının uzun süre temizlenmemesi, ziyaretçilerin serzenişlerine sebep olmuş ve Yeni Konya Gazetesi de konuyu sütunlarına taşıyarak belediye yetkililerini uyarmıştır ${ }^{146}$.

İplikçi Caminin minaresinin İşadamı Mehmet Karacığanlı tarafından yaptırılacağı ve inşaatın Mayısta başlayacağı, Alaaddin ve Emsali Camileri Yaptırma ve Onarım Derneğinin de camiye bir tuvalet yaptırmak istediği, derneğe başvuran İranlıların da Mevlana'ya olan hürmetlerinden dolayı camiye bir kitaplık yaptırma arzuları ${ }^{147}$ ve yine dernekçe, cami bahçesinde ağaçlandırma çalışmalarına başlandığı bilgisi kamuoyuna duyurulmuştur ${ }^{148}$.

Japon Prensi Mikasa ve Eşi Dün Geldi ve Gittiler başlığı ve Japon Prens ile eşinin fotoğrafı ile manşetten verilen habere göre, 15 Nisan 1963 tarihinde Türk Hava Kuvvetlerine ait bir uçakla 12:45 te Konya'ya inen Japon Prens ile maiyeti, kendilerine düzenlenen törenden sonra Şeker fabrikasında yemek yemişler, 17:15 te Konya'dan ayrılmadan önce de sırası ile Mevlana Müzesi,

140 Yeni Konya, 21 Ocak 1963, s.1.

141 Şehir Postas1, 30 Ocak 1963, s.1.

142 Şehir Postası, 6 Şubat 1963, s.1.

143 Yeni Meram, 21 Şubat 1963, s.1.

144 Yeni Meram, 6 Mart 1963, s.1.

145 Şehir Postası, 9 Mart 1963, s.2.

146 Yeni Konya, 19 Mart 1963, s.1.

147 Kitaplık yeri olarak Mevlana'nın ikamet ettiği ilk hücre düşünülmüştür.

148 Yeni Meram, 15 Nisan 1963, s.1. 
Klasik Eserler Müzesi, İnce Minare, Karatay Medresesi ve Alaaddin Camini gezmişlerdir ${ }^{149}$. Görüldüğü üzere, Japon heyeti kente önem verdikleri bu tarihi eserleri görmeye gelmişler ve hedeflerini gerçekleştirdikten sonra ayrılmışlardır. Konya müzeleri ve tarihi eserlerinin dünyadaki algılanışı ve durumu açısından önemli örneklerden birisi de Japon Prensi Mikasa'nın ziyaretidir. Aynı günkü gazetelerde çalışma konumuz ile alakalı bir diğer haber de Profesör Mellaart'ın Çatalhöyük kazılarına yeniden başlayacağı ve bu yaz ağırlıklı olarak neolitik mabetlerin ortaya çıkarılması konusuna yoğunlaşacağıdır ${ }^{150}$.

Nisan 1963'te açıklanan Konya'nın 5 Yıllık Turizm Planına göre; Kentteki turizmi geliştirmek amacıyla 7 maddelik (kimi maddeler çeşitli alt maddelere bölünmüştür) bir eylem planı hazırlanmıştır. Bu planın konumuzla alakalı kısımları: Mevlana İhtifallerinin daha ihtişamlı kutlanması, Müze Caddesindeki dükkânlardan birisinin Turizm Derneğine tahsis edilmesi ve Karaman Binbir Kilise yolunun bakıma alınmasıdır ${ }^{151}$. Aynı günkü bir başka haberde ise Koyunoğlu Müzesine yeni vitrinler yaptırmak için çeşitli kuruluşların yarıştığı, son siparişi veren Sümer Bank'tan sonra sırada Türkiye Kredi Bankasının bulunduğu bilgisi verilmiştir ${ }^{152}$.

En çok ziyaret edilen müze Mevlana müzesi başlığı ve müzenin dış ve içten 2 fotoğrafı ile manşetten verilen habere göre, Mevlana Müzesi bir önceki yıl 75 bini yabancı olmak üzere 350 bin kişi tarafından ziyaret edilmiştir. Uzmanlar bu sayının 1963 te 400 bini geçeceğini düşünmektedirler. Haberin devamında müzenin kısımları tanıtılmakta ve gelecekte düşünülen eklentilerden bahsedilmektedir ${ }^{153}$.

Sahip Ata, Sultan Selim ve Alaaddin Camilerinin 1963 yılı onarım ihalesinin, kapalı zarf usulü ile, 15 Mayıs Çarşamba günü saat 10:00 da Vakıflar Müdürlüğü binasında gerçekleştirileceği ve açlış bedelinin 113 bin 229.93 lira olduğu bilgisi, 25 Nisan tarihli yerel basında kendisine yer bulmuştur ${ }^{154}$.

UNESCO Romen Milli Komisyonunca organize edilen, başta Romanya olmak üzere Avrupa'nın çeşitli ülkelerinde gerçekleştirilecek olan fotoğraf sergisi için Konya' dan 10 fotoğraf talep edilmiş, Konya Müze Müdürlüğü gerçekleştirilen hummalı çalışmanın sonrasında seçilen fotoğrafları sergilenmek üzere ilgili makamlara teslim etmiştir ${ }^{155}$. Konya'da dönemin önemli kalemlerinden Selçuk Es, yazdığı bir makale ile İnce Minare hakkında bilgiler vermiş ve tamiri konusunu yeniden yetkililere hatırlatma lüzumunu hissetmiştir ${ }^{156}$.

Nisan ayında Konya'ya günübirlik bir gezi yapmış olan Japon Prensi Mikasa, kendisine gösterilen ilgiye teşekkür etmek amacıyla Konya Valisi Rebii Karatekin'e gümüş, Japon motifli, yarım küre şeklinde bir masa biblosu hediye etmiş, Rebii Bey de şahsına gönderilen bu hediyeyi Mevlana Müzesine bağışlamıştır. Valinin örnek davranışı müze yetkilileri ve halk tarafından takdirle karşılanmışıı ${ }^{157}$. Vali Rebii Karatekin tarafından başlatılan çalışma ile Atatürk Müzesi

\footnotetext{
149 Yeni Konya, 16 Nisan 1963, s.1.

150 Yeni Konya, 16 Nisan 1963, s.1.

151 Yeni Konya, 17 Nisan 1963, s.1.

152 Yeni Konya, 17 Nisan 1963, s.1.

153 Yeni Konya, 22 Nisan 1963, s.1-3.

154 Şehir Postası, 25 Nisan 1963, s.1. İhale keşif bedeli Yeni Meram Gazetesinde 113 bin 294 lira olarak verilmiştir. Ayrıntı için bkz. Yeni Meram, 27 Nisan 1963, s.1.

155 Seçilen fotoğraflar: Karatay Medresesi, Çini Eserler Abidesi, Sahip Ata Külliyesi, Alaaddin Cami Minberi, Kubbe-i Hadra, Mevlana'nın Sandukası, Selçuklu Arması, Ahşap Pencere Kanadı, Ulaş Baba Kümbeti (Gazetede 9 eserin adı geçmektedir) şeklindedir. Yeni Konya, 26 Nisan 1963, s.1-2.

156 Selçuk Es, Yıldırımdan Yıkılan İnce Minarenin Minaresi Hakkında, Yeni Konya, 28 Nisan 1963, s.3.

157 Yeni Konya, 1 Mayıs 1963, s.1.
} 
haline getirilmesi düşünülen vali konağı binasında gerekli incelemeleri yapmak üzere Müzeler Genel Müdürlüğünden bir Yüksek Mimar Konya' ya gelmiş ve çalışmalara başlamıştır ${ }^{158}$.

Konya basınında manşetten verilen 17 Mayıs 1963 tarihli habere göre, Vakıflar Genel Müdürlüğü, kent merkezi ve ilçelerde belirli vasıfları taşıyan 32 camiye 47 bin 500 lira yardım yapacaktır. Haberde camilerin adları ve bulundukları yer detaylandırılmışırı1 ${ }^{159}$. Mayıs ayının çalışma konumuz ile ilgili basına yansıyan son haberi; Çinileri bu yıl yenilenecek başlığı ile verilen, Mevlana Türbesinin çinilerinin yenilenmesi ile ilgili metindir ${ }^{160}$.

Haziran ayında Koyunoğlu Müzesinde fotoğraf çekmek isteyen bir İsviçreli arkeoloğun uyarıları sonucu yapılan kontrollerde, Hitit Sarayına ait paha biçilemez bir Havaneli ile başka değerli eşyaların kayıp olduğu görülmüş ve konu emniyet güçlerine aksettirilmiştir ${ }^{161}$. Mayıs ayı içerisinde ihalesi yapılan projelerden Alaaddin Camisinin onarım işinin Temmuz ayı içerisinde başlayacağı ise Haziran ayının bir başka haberidir ${ }^{162}$. Yazın ilk günlerinin bir diğer haberi ise Konya Turizm Cemiyeti Başkanı Feyzi Halıcı'nın John Mellaart ile yaptığı görüşme ve Mellaart'ın yıllık kazı işlerinin sonunda cemiyet binasında bir konferans vereceğini açılamasıdır ${ }^{163}$. Aynı gün basına yansıyan bir diğer bilgi, devam etmekte olan Kapı Cami tamiratının eserin orijinalliğine zarar vermemek için durdurulduğu ve Ankara'dan Vakıflar Genel Müdürlüğünden uzman bir teknisyenin beklenmeye başladığ1 şeklindedir ${ }^{164}$. Kap1 Caminin inşaatının devamı için hayırseverlere yapılan yardım çağrısı da Konya basınında kendisine yer bulmuş bir diğer havadistir165. Haziran ayının son günlerinde, Selçuk Es'in Konya Hükumet Konağı binasını tanıtıp tarihçesini verdiği bir makale yayınlanmıştır ${ }^{166}$

8 Temmuz 1963 tarihinde Konya Valisi Rebii Karatekin tarafından, Kız Öğretmen Okulunda açılan Selçuklu Eserleri Rölöve Sergisinde çok ilginç Selçuklu eserleri halkın beğenisine sunulmuştur ${ }^{167}$. Dönemin Konya basınının tarihi eserler ve arkeoloji konusuna yaklaşımına örnek olmak üzere, Şehir Postası Gazetesi Panorama köşesinde 15 Temmuz tarihinde çıkan isimsiz makale oldukça önemlidir. Türkiye'de yapacağı kazılarda yeni teknik kullanacak başlıklı metinde, yarım sayfadan uzun bir şekilde Güneydoğu'daki Kommagene kazıları hakkında bilgiler verilmiş ve gelecek günlerde beklenen gelişmeler duyurulmuştur ${ }^{168}$.

18 Temmuzda CHP Konya Milletvekili İhsan Kabadayı'nın açıklamasına göre, Vakıflar Genel Müdürlüğü 14 Konya camisine ikinci kez para yardımı yapmıştır. Haberin devamında camilerin isimleri ve aldıkları yardım miktarları belirtilmiştir ${ }^{169}$. Ertesi gün köşesinde, tarihi eser kaçakçılığı konusunda yazan Seyit Küçükbezirci, halkı bu konuda bilinçlendirmeye çalışmıştır ${ }^{170}$. Turizm ve Tanıtma Bakanı Nurettin Ardıçoğlu 28 Temmuz günü Ankara'da düzenlediği basın toplantısında verdiği çeşitli bilgilerin yanı sıra, Konya Turizm ve Tanıtma Müdürlüğünün de kurulduğunu açiklamıştır ${ }^{171}$.

Vali Rebii Karatekin, maiyetindeki kent bürokratları ile 1 Ağustos 1963 te Çatalhöyük kazısını ziyaret etmiş ve hem kazı faaliyetleri hem de ileride bölgeye yapılması düşünülen

158 Yeni Konya, 10 May1s 1963, s.1.

159 Şehir Postası, 17 Mayıs 1963, s.1.

160 Yeni Meram, 24 Mayıs 1963, s.1.

161 Yeni Konya, 4 Haziran 1963, s.1.

162 Yeni Meram, 6 Haziran 1963, s.1.

163 Şehir Postası, 8 Haziran 1963, s.1.

164 Yeni Konya, 8 Haziran 1963, s.1-4.

165 Yeni Konya, 14 Haziran 1963, s.1.

166 Selçuk Es, Hükümet Kona ̆̆g, Şehir Postası, 24 Haziran 1963, s.2.

167 Yeni Meram, 8 Temmuz 1963, s.1.

168 Şehir Postası, 15 Temmuz 1963, s.3.

169 Şehir Postası, 18 Temmuz 1963, s.1-3.

170 Seyit Küçükbezirci, Tarihi Eser Kaçakçılı̆̆ı Üzerine, Şehir Postası, 19 Temmuz 1963, s.2.

171 Şehir Postası, 29 Temmuz 1963, s.1-4. 
turistik tesisler hakkında bilgi almıştır ${ }^{172}$. Turizm ve Tanıtma Bakanı Nurettin Ardıçoğlu, makama geldikten sonra ilk ziyaretini Konya'ya gerçekleştirmiş, 5 Ağustos tarihinde geldiği kentte, Konya Turizm ve Tanıtma Müdürlügüne Hicret Cambazoğlu'nun atandığını açıklamış ve bakanlığın kente verdiği önemden bahsetmiştir. Bakanın, Konya seyahatinin basına yansıdığı gün ayrıca, Vakıf İşhanı ve Karaman İbrahim Bey İmaretinin onarım ihale duyuruları da kamuoyu ile paylaşılmıştır ${ }^{173}$.

Konya Müzeleri Devamlı Olarak Ziyaret Edilebilecek başlı̆̆ ile verilen haberde; Konya Turizm Derneğinin yevmiyeli personel çalıştırılması ve masrafının dernekçe üstlenilmesi, bunun neticesinde Konya müzelerinin Pazartesileri ve haftada bir gün tüm gece açık olması projesinin, Konya Müze Müdürlüğünce olumlu karşılandığ ve uygulamaya yakında başlanacağı bilgisi verilmiştir ${ }^{174}$. Bir diğer haberde ise Mevlana Müzesi meydanında görülen kirlilik ve düzensizliğin giderilmesi için belediye yetkililerine seslenilmiştir ${ }^{175}$.

Milli Eğitim Bakanlığı Resim ve Eski Eserler Müfettişi Hasan Kavruk, 1 Eylül 1963 tarihinde Konya'ya gelmiş ve çeşitli eski eserleri tetkik etmiştir ${ }^{176}$. Bu arada basında Mevlana Müze Meydanının düzenlenmesi ile ilgili yazılar çıkmaya devam etmiş, 12 Eylül tarihli baskıda, meydanın uygun yerlerine çöp tenekelerinin konması istenmiştir ${ }^{177}$.

Eski Eserleri Onarma Derneği yaptığı açıklamada; Tacü'l Vezir Türbesi ve Emir Nurettin Türbelerinin onarımının tamamlandığını, İnce Minare Müzesi ile Selçuklu Köşkünde çalışmaların devam ettiğini, gelecek yıl ise Fahrunnisa Hatun Türbesi ile Yeşil Türbenin çinilerinin ele alınacağını kamuoyuna duyurmuştur ${ }^{178}$. Ayrıca basına yansıyan bir diğer açılamada ise 1964 yılında Mevlana Müzesinin, Turizm ve Tanıtma Bakanlığınca onarılacağı bilgisi verilmiştir179. Ayrıca, İmar ve İskân Bakanı Fahrettin Kerim Gökay, yaptığı basın toplantısında, Konya Mevlana Müzesinin etrafının istimlak edilerek genişletileceğini söylemiştir ${ }^{180}$.

Mehmet Önder, 23 Kasımda yerel basında yayınladığı makale ile Türk Müzecilik Tarihi ve Konya Mevlana Müzesinin açılışı hakkında halkı bilgilendirmeye çalışmıştır ${ }^{181}$. Konya'ya Bir Askeri Müze Açılması Bekleniyor başlı̆̆ ile verilen habere göre ise çeşitli mahfillerde Konya'ya bir askeri müze açılması konusunda çalı̧̧malar yapılmaktadır. Haberin devamında böylesi bir müzenin Konya'ya getireceği faydalar sıralanmıştır ${ }^{182}$.

690. Mevlana İhtifalleri 7 Aralık tarihinde başlamış ve kente büyük bir turist akını gerçekleşmiştir. Törenlere katılacak vatandaşların rahat etmesi için İstanbul-Konya trenlerinin sayısı arttırılmıştır ${ }^{183} .8$ Aralık tarihli Yeni Konya Gazetesinin ilk sayfası ise neredeyse tamamen Mevlana İhtifalleri haberlerine ayrılmıştır. Mevlana'nın sandukasının fotoğrafının da yer aldığı ilk sayfada, Konya'ya gelen fakat otellerde yer bulamayan yerli ve yabancı turistlerin, Konya halkınca misafir edildiği bilgisi verilmiş, PTT'nin spor salonuna törenler boyunca hizmet verecek geçici bir şube açtığı aktarılmış, Konya Müftüsünün kent halkına gelen turistlere nasıl davranılması gerektiğiyle ilgili 4 maddelik tavsiyeleri yazılmış ve İl Halk Kütüphanesinde bir

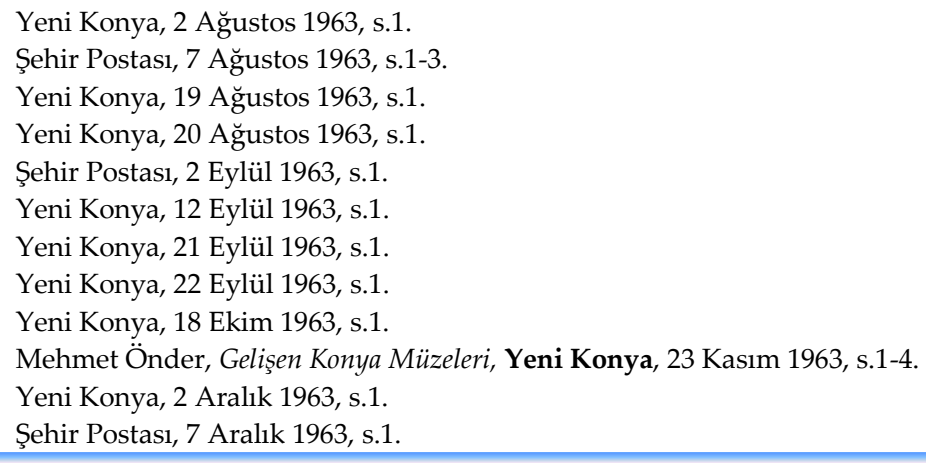


hafta süreyle Mevlana konulu sergi açıldığı bildirilmiştir ${ }^{184}$. Yine ilk sayfada İhsan Olgun'a ait Türk kültürü ve Mevlana'yı anlatan bir makale yayınlanmıştır ${ }^{185}$. Mevlana törenleri için kente gelen kalabalıklar, Konya müzelerinin de dolup taşmasını sağlamış, iki gün içerisinde aralarında önemli şahsiyetlerin de olduğu 9 bin kişi Konya müzelerini ziyaret etmişlerdir ${ }^{186}$.

Konya yerel basınında tarihi eserler ile ilgili yayınlar çıkmaya devam etmiş, 14 Aralık tarihinde Beyhekim Mescidi ve Sırçalı Mescit'in mihraplarının fotoğrafları Yeni Konya Gazetesinin ilk sayfasında okurlar ile paylaşılmıştır ${ }^{187}$. Yılın konumuzla alakalı son haberi ise Baro Başkanı Tahir Mıhçızade'nin yazma ve basma eserlerden oluşan şahsi kitaplığını Mevlana Müzesine bağışlamasıdır ${ }^{188}$.

\section{Yılında Konya'da Tarihi Eser ve Turizm Çalışmaları}

1964 yılının konumuz ile alakalı ilk haberi, Karaman Gizli Kilise'nin uzaktan bir fotoğrafının da kullanıldığı, turizmin geliştirileceği ve bütçe açığının bu şekilde kapatılacağından bahsedilen metindir ${ }^{189} .1963$ Konya Müzeleri İçin Rekor Yılı Oldu başlıklı haberde ise toplam 324 bin 406 kişinin 1963 yılında Konya müzelerini gezdiği ve bunların 24 bininin yabancı olduğu bilgisi verilmiştir ${ }^{190}$.

Bu arada, Milli Eğitim ve Maliye Bakanlıklarının aldığı bir kararla, Türkiye'deki müze giriş ücretleri \%100-150 arasında artmıştır. Böylelikle 100 kuruş olan Mevlana Müzesi giriş ücreti, 250 kuruşa çıkmıştır. Cumartesi ve Pazar günleri bu ücret 125 kuruştur. Müze yetkilileri Mevlana'nın bir ziyaretgâh olduğunu bildirerek ücretin indirilmesi için ilgili makamlara müracaatta bulunmuştur'191.

İmar ve İskan Bakanlığı bütçesinden 1 milyon liralık bir meblağ, Konya Mevlana Türbesi ve Edirne Selimiye Cami civarının istimlak işlerinde kullanılmak üzere ayrılmış, bu durum Konya ve Mevlana'ya verilen önemin bir göstergesi olarak kent basınında ilgi görmüştür ${ }^{192}$. Aynı gün bir başka güzel haber; sahibi tarafından ücretsiz olarak hizmette olan Koyunoğlu Müzesinden belediyece alınan bir kararla elektrik ve su fatura ücreti alınmayacağ

Daha önce 11 bin liralık bir el yazması Mesneviyi, Mevlana Müzesine bağışlayan İş Bankası, 6 bin liralık yeni bir vitrini de müzeye hediye etme kararını yetkililere bildirmiş, bu haber sevinçle karşılanmıştır ${ }^{194}$. Tanzim işleri devam eden ve kültür müzesine dönüştürülecek olan Atatürk Evinin taban halıları ve kadife perdelerinin yaptırılma işini de Sümerbank üstlenmiş, bu haber de Konya mahfillerinde memnuniyet yaratmıştır ${ }^{195}$.

Vali Rebii Karatekin başkanlığında oluşturulan İl Turizm Komitesi teşkilatlanmasına devam ederek, Akşehir, Beyşehir ve Karaman İlçe Turizm Komiteleri kurulmuş, bu komitelerin faaliyete geçiş tarihi olarak da Mart ayı gösterilmiştir. Konya Turizm Müdürlüğü binasının yapımı içinse, belediyeden arsa satın alınarak inşaat planlarına başlanmıştır ${ }^{196}$.

Yeni Konya, 8 Aralık 1963, s.1-4.

185 İhsan Olgun, Mevlâna, Yeni Konya, 8 Aralık 1963, s.1.

186 Yeni Konya, 10 Aralık 1963, s.1.

187 Yeni Konya, 14 Aralık 1963, s.1.

188 Yeni Konya, 16 Aralık 1963, s.1.

189 Şehir Postası, 3 Ocak 1964, s.1.

190 Yeni Konya, 6 Ocak 1964, s.1-3.

191 Şehir Postası, 22 Ocak 1964, s.1.

192 Yeni Konya, 23 Ocak 1964, s.1.

193 Yeni Konya, 29 Ocak 1964, s.1.

194 Yeni Konya, 7 Şubat 1964, s.1.

195 Yeni Konya, 10 Şubat 1964, s.1.

196 Yeni Konya, 20 Şubat 1964, s.1. 
Antik Eser ve Eşyalar Yurtdışına Kaçırılıyor başlığıyla 14 Mart 1964 tarihinde verilen bir haber ile Konya'ya gelen bazı turistlerin tarihi eser vasfı taşıyan birtakım eşyaları antikacılardan alarak yurtdışına çıkarttıklarının il emniyet müdürlüğünce tespit edildiği ve bunun önlenmesi için müze müdürlüğü ile birlikte ortak bir projeyi hayata geçirerek, antika ve hediyelik eşya satıcılarını bilgilendirmeye başladıkları kamuoyuna duyurulmuştur ${ }^{197}$.

Dönemin Beyşehir Kaymakamının, ilçede bulunan Eşrefoğlu Camisinin yıkılma tehlikesi karşısında, yetkilileri uyarmasına rağmen hala bir çalışmanın başlatılmadığı serzenişi ve Konya'da yapılacak modern turizm ofisi için Ankara'dan bir yüksek mimarın gelerek kentte çalışmalara başladığı bilgisi aynı gün Konya basınına düşen haberlerdir ${ }^{198}$. Bu arada Sümerbank, Hereke de bulunan fabrikasında 104 metrekare büyüklügünde, 400 kilo ağırlığında ve 50 milyon dügüm ihtiva eden yekpare bir halı dokutarak Mevlana Müzesine hediye etmiştir. Sümerbank'ın açılacak Atatürk Evi içinde 6 adet halı dokuttuğu kamuoyunca bilinmektedir ${ }^{199}$. Paragraf başında belirtilen Beyşehir Kaymakamının serzenişine, Konya Valisi Rebii Karatekin'in olumlu tepkisi gecikmemiş, Ankara ile yaptığı temaslar neticesinde gereken kaynağı oluşturan vali, Eşrefoğlu Caminin onarımı için çalışmaların hemen başlayacağını duyurmuştur ${ }^{200}$.

28 Mart 1964 tarihi, Konya ili tarihi eserler ve turizmi açısından, 3 ilk sayfa haberinin basında görüldüğü bir gün olmuştur. Beyşehir Eşrefoğlu Caminin onarımı için başlatılan çalışmalar kapsamında Ankara'dan gelen 2 mimar, adı geçen camide incelemeler yapmaya başlamış, Çatalhöyük kazı alanını görmek isteyen yerli ve yabancı turistlerin işlerini kolaylaştırmak amacıyla buraya ulaşımı sağlayan 15 kilometrelik ham yolun en azından stabilize hale getirilme projesi Karayollarınca üstlenilmiş ve Konya hakkında son 30 yılda çıkan yayınların envanteri kamuoyu ile paylaşılmıştır. Bu çalışmaların ağırlığını tarihi eser konuları ile Mevlana hakkında neşredilenler oluşturmaktadır201.

Çalışma konumuzla ilgili 5 ilk sayfa haberinin verildiği 30 Mart tarihi de Konya kamuoyunun tarihi eser ve turizm konularında bilgilendirildiği önemli bir gün olmuştur. Manşetten verilen Konya Bir Müze Daha Kazanıyor başlıklı haberde, düzenlenen Atatürk Evinin, kentin 7. Müzesi olarak başlangıçta 4 pavyonu ile açılışının yakında yapılacağı duyurulmuştur. Diğer haberlerde ise sırası ile Beyşehir İlçesinin yetkililerinin Eşrefoğlu Camisinin avlusunda bir müze kurulması için müracaat ettikleri ve ayrıca yakında Kubadabat Sarayı kalıntılarında kazı çalışmalarına başlanacağı, ilkbaharın gelmesi ile birlikte Konya'ya gelen yerli ve yabancı turistlerin arttığı; Alman Deniz Ataşesi ve eşinin de kente gelerek müzeleri ziyaret ettiği, Sille'de bulunan gömme kiliselerin restorasyonuna başlanacağı ve büyük kilisenin müze yapılmasının düşünüldüğü, Bozkır, Ereğli ve Ilgın ilçelerinin de müzeler müdürlüğüne başvuruda bulunarak bölgelerinde birer müze açılmasını istedikleri şeklindedir ${ }^{202}$.

1964 yılının Nisan ayında çalışma konumuz ile ilgili yayınların ağırlığı Şehir Postası Gazetesinde gerçekleşmiştir. Kronolojik olarak ana hatları ile bu haberleri değerlendirmek gerekir ise Konya Müze Müdürü Mehmet Önder, Karaman Müzesinin tanzimi ve eserlerin değerlendirilmesi için 2 günlügüne ilçeye gitmiştir ${ }^{203}$. Ereğli'nin Ambar Köyünde bulunan Bizans ve Roma kalıntılarının definecilerce yağmalandığı, buna da eserlerin başına bir bekçi

97 Şehir Postası, 14 Mart 1964, s.1.

198 Şehir Postası, 24 Mart 1964, s.1.

199 Yeni Konya, 25 Mart 1964, s.1.

200 Yeni Konya, 26 Mart 1964, s.1.

201 Şehir Postası, 28 Mart 1964, s.1.

202 Yeni Konya, 30 Mart 1964, s.1-2.

3 Şehir Postası, 3 Nisan 1964, s.1. 
atanmamasının neden olduğu kent basınında tartışılan bir haber olmuştur ${ }^{204}$. Dönemin Şehir Postası Gazetesinde adı Naydin Buxtom ${ }^{205}$ olarak verilen İngiltere'nin Sunday Telegraph Gazetesinin ünlü seyahat yazarı Ankara üzerinden Konya'yı ziyaret etmiş, müze ve tarihi eserleri gördükten sonra Antalya'ya doğru kentten ayrılmıştır ${ }^{206}$. Karaman ilçesi yetkililerinin girişimi ile Konya'da dükkânlarında satmak amacı ile çeşitli miktarlarda kayıtsız tarihi eser bulunduran sarraf, eskici, kuyumcu gibi 8 kişinin hem isimlerinin hem de bulunan malların envanterinin verildiği listenin ilk sayfadan yayınlanması önemli etki bırakan haberlerdir ${ }^{207}$. Vali Rebii Karatekin başkanlığında 17 Nisanda gerçekleştirilecek turizm konulu toplantının katılımcılarına bakıldığında kentte konuya verilen önem daha iyi anlaşılmaktadır. İlgili toplantıya validen başka, belediye başkanı, İl Turizm Komitesi üyeleri, ilgili daire müdürleri, merkez komutanı, orduevi müdürü, merkez ilçe nahiye müdürü ve ilçe belediye başkanları katılacaklardır ${ }^{208}$. Konya Turizm Derneğinin yıllık programı da bu ay içerisinde açıklanmış ve özellikle turistlerle ilk temas eden müstahdemlere dil kursu açılması projesi dikkat çekmiştir ${ }^{209}$. $\mathrm{Bu}$ arada Beyşehir gölünün kıyısına bir kamping inşaatına başlanmıştır ${ }^{210}$. Turizm Tanıtma Bakanlığı tarafından Konya'daki 4 turizm derneğine 45 bin lira ${ }^{211}$ ve Vakıflar Genel Müdürlüğü tarafından il genelinde 62 camiye 85 bin lira yardım yapıldığı haberleri de basına yansıyan diğer bilgiler olmuştur ${ }^{212}$. Nisan ayının son haberi ise Akşehir İlçesinde başta ilçe kaymakamı olmak üzere tüm önde gelenlerin bölgede turizmi geliştirme adına toplanıp çeşitli kararlar almaları ve Vali Rebii Karatekin'in Karaman'a ilçe turizm toplantısı için gitmesi olmuştur ${ }^{213}$.

Norveçte Çatalhöyükle İlgili Yayın Yapıldı başlığı ile verilen haberde, Konya Turizm Derneğinin temasları sonucunda Norveç'in Hallingdal Gazetesinde Çatalhöyükle ilgili resimli tanıtım yazısı yayınlanmış, bu duruma sevinen dernek yetkilileri, Çatalhöyük hakkında bir tanitım broşürü hazırlamaya karar vermişlerdir ${ }^{214}$.

Vali Rebii Karatekin başkanlığında toplanan Ereğli İlçe Turizm Komitesi, Ambarlı Köyündeki eski eserlerin mahalli imkânlarla korunması, Rüstem Paşa Kervansarayına müze açılması, İvriz yolunun onarılması, ilçeye turistik bir otel inşası ve turizm derneği enformasyon binasının oluşturulması kararını almıştır. Aynı gün kamuoyuna daha önce bahsi geçen Turizm Derneğinin açacağ dil kursunun derslerinin 15 Mayısta başlayacağı duyurusu yapılmıştır ${ }^{215}$.

Ereğli'nin Beğendik Köyünde, Hititlere ait olduğu tahmin edilen büyük bir tarihi şehir kalıntısının bulunması ve Akşehir'de Batı Cephesi Karargâh binası olarak da kullanılan Atatürk Evinin, Askerî Müzeye dönüştürülme kararı 9 Mayıs 1964 tarihinde Konya kamuoyuna duyurulan haberler olmuşlardır ${ }^{216}$.

Sille'de bulunan kaya kiliselerinde çalışma yapan Alman televizyoncuların eşlerine yapılan birtakım tacizlerin Konya'da gündeme gelmesinin ardından konuyu iş edinen Sille halkı, yaptığ1 araştırmalar sonucunda 2 tacizciyi belirlemiş ve afişe ederek halk nazarındaki itibarlarını azaltmıştır. Bu durum bölge halkının turiste verdiği önemin de bir göstergesidir.

204 Yeni Konya, 6 Nisan 1964, s.1.

205 Asıl adı Nigel Edward Buxton (1924-2015) İngiliz seyahat yazarı ve gazeteci. Ayrıntılı bilgi için bkz. https://en.wikipedia.org/wiki/Nigel_Buxton.

206 Şehir Postası, 8 Nisan 1964, s.1.

207 Şehir Postası, 10 Nisan 1964, s.1.

208 Şehir Postası, 15 Nisan 1964, s.1.

209 Şehir Postası, 16 Nisan 1964, s.1.

210 Şehir Postası, 18Nisan 1964, s.1.

211 Şehir Postası, 20 Nisan 1964, s.1.

212 Şehir Postası, 27 Nisan 1964, s.1.

213 Şehir Postası, 30 Nisan 1964, s.1.

214 Şehir Postası, 1 Mayıs, s.1.

215 Şehir Postası, 7 Mayıs, s.1.

216 Yeni Konya, 9 May1s 1964, s.1. 
Aynı günlerde Konya Turizm Derneği ön yüzü Türkçe, arka yüzü Almanca, Fransızca ve İngilizce basılı tanıtım broşürleri bastırmıştır. Seçilen diller dönemin Konya'ya gelen turistlerinin iletişim dilleri hakkında da fikir vermektedir. Türkiye de yayın yapan Amerikan Daily News Gazetesinde çıan, Vali Rebii Karatekin'in tarihi eserler ve turizm konulu çalışmalarını öven ve Türkiye'de ikamet eden Amerikalıları hafta sonları için bile olsa Konya'yı ziyaret etmeye davet eden haberlerde kent kamuoyunda memnuniyet oluşturmuştur ${ }^{217}$.

Konya Müze Müdürü iken Eski Eserler ve Müzeler Genel Müdürlügüne atanan Mehmet Önder, 17 Mayıs 1964 tarihinde Konya'yı ziyaret etmiş ve Mevlana Müzesi ile Konya Klasik Eserler Müzesinin geliştirilmesi için büyük çaplı istimlakler yapılacağını, Arkeoloji Müzesi açılacağını, il sınırları kapsamında bulunan arkeolojik eserlere hızla ulaşılması için bir otomobil tahsis edileceğini, açılmış ve açılacak olan ilçe müzeleri programının yeniden ele alınacağı ile Konya'da bulunan eski eserlerin tescil işlemlerinin 1964 yılı sonuna kadar tamamlanacağını açılamıştır ${ }^{218}$.

Mayıs ayının diğer haberlerine topluca göz atmak gerekirse, Sille Turizm ve Tanıtma Derneği, Aya Eleni kilisesinin bahçe duvarlarının onarımının başlatıldığını kamuoyuna duyurmuştur ${ }^{219}$. Bu arada turistlerin sıkça ziyaret ettiği kilise ve Sille bölgesine rahat ulaşım amacıyla Konya-Sille arasında 16 kilometrelik yeni yol yapımına karayollarınca başlanmışıı²20. 28 Mayıs tarihinde ise Ziraat Bankası İdare Meclisi Üyeliğine atanan Vali Rebii Karatekin'in bu görevden istifası ve emeklilik durumunun gündeme gelmesiyle birlikte, Konya gazetelerinde kentin çeşitli teşekküllerinin valinin göreve devamı için Ankara'ya gönderdikleri rica telgrafı metni yayınlanmıştır 221 .

1964 Haziranı Vali Rebii Karatekin'in emekliye ayrıldığı dönemdir. 3 Haziran tarihinde Karatekin'in kentte gerçekleştirdiği veda ziyaretleri basına yansımış, aynı gün Mehmet Önder'in Konya müzelerinin yılda 400 bin kişi tarafından ziyaret edildiğini açıkladığı konuşması da kamuoyuyla paylaşılmıştır ${ }^{222}$. Valinin emekli olup kentten ayrılacak olması dolayısıyla Konya eşrafı, kurum ve kuruluşlar çeşitli aktiviteler düzenlemişler, çok sevdikleri valiye çeşitli hediyeler takdim ederek onu uğurlamışlardır. Bu arada Rebii Karatekin'in Konya'ya veda mesaj1 5 Haziran 1964 tarihinde ilk sayfa haberi olarak yayınlanmıştır ${ }^{223}$.

\section{SONUÇ}

İnsanlık tarihinin en eski yerleşim alanlarından birisi olan Anadolu ve Konya, bu özelliği ile önemli bir tarih ve eski eser potansiyeline sahiptir. Üst üste kurulan medeniyetler ve yapılan eserler, Konya kent merkezi ile il sınırlarının bu noktada çok zengin olmasını sağlamaktadır. Tarihi süreçte halk tarafından yeterince bilinmeyen bu tarihi eserler, özellikle cumhuriyetin kurulmasından sonraki dönemde yavaş yavaş hak ettikleri öneme kavuşmaya başlamışlardır.

Özellikle İkinci Dünya Savaşından sonra turizmin dünya genelinde gelişmesi ve gezi rotalarının sadece doğal güzelliklere yönelik olmayıp; tarihi ve kültürel noktaları da kapsaması, Konya ve Türkiye için önem arz etmiştir. Tam da bu dönemde eğitim, tarihi eser ve turizm sevdalısı bir bürokrat olan Rebii Karatekin Konya Valisi olmuştur.

17 Şehir Postası, 13 Mayıs 1964, s.1.

8 Yeni Konya, 18 May1s 1964, s.1.

9 Şehir Postası, 20 Mayıs 1964, s.1.

220 Şehir Postası, 21 Mayıs 1964, s.1.

221 Yeni Konya, 28 May1s 1964, s.1-3.

222 Yeni Konya, 3 Haziran 1964, s.1-3.

223 Yeni Konya, 5 Haziran 1964, s.1. 
Rebii Karatekin'in göreve başlaması ile Konya'nın var olan potansiyelinde hızlı bir artış görülmüş; yönetici ve aydınların başlattığı yürüyüşe kent halkı da severek iştirak etmiştir. Rebii Karatekin dönemi Konya basını incelendiğinde, kentin tarihi eserler ve turizm konusuna bakışı net bir şekilde ortaya çıkmaktadır.

Dönemin Konya basını, turizm ve tarihi eserler konusuna verdiği önemi, bazı günler ilk sayfada (hatta manşetten) verdiği 4-5 haberle pek çok kez göstermiştir. Konya tarihi ve eserler konusunda sık sık halkı bilgilendiren haber ve makaleler yayınlanmıştır. Özellikle haberler kısmında, dünyadaki tarihi eser ve turizm politikalarından örnekler verilmiş, kent halkına ulaşılması istenen hedef noktası gösterilmiştir. Bunun bir yansıması olarak da adı geçen dönemde Konya'da pek çok tarihi eser koruma, yardım, onarım, yaşatma ve turizm dernekleri kurulmuş; oluşturulan bu organizasyonlar da atıl vaziyette olmayıp, aktif bir şekilde sahada hizmet etmişlerdir.

Anadolu'nun en eski yerleşim alanlarından birisi olan Çatalhöyük kazılarına da Rebii Karatekin döneminde başlanmıştır. Kentin genel havasının bir yansıması olarak da kazı, şehir basınında sıklıkla konu edilmiş, bunun yanı sıra dünyanın çeşitli önemli kazıları hakkında bilgilendirici yazı ve haberler yayınlanmıştır. Konya'da kazı çalışmalarını yürüten James Mellaart, Sedat Alp vb. önemli bilim adamları ile ilgili yapılan haberler ve röportajlar da basının konuya gösterdiği ilginin bir diğer göstergesi olmuştur. Kazı, tarihi eser, müze ve müzecilik konularında Konya basınında en çok yazan, halkı bilinçlendirmeyi görev addeden kişilerin başında da dönemin Konya Müze Müdürü Mehmet Önder gelmiştir.

1960-1964 yılları arasında, Konya'da hiç şüphesiz en çok ilgi gören faaliyet geleneksel Mevlana İhtifalleri olmuştur. Dünya çapında vizyonu olan bu etkinliğe, her yıl birçok önemli konukla birlikte farklı ülkelerden ziyaretçiler katılmıştır. Bu denli önemli olan ihtifal, Mevlana ve türbesi ile ilgili haberler ise Konya basınının sıklıkla ve ciddiyetle ele aldığı metinler olmuştur.

Mevlana Türbesi ve müzesi de Konya'nın ve Türkiye'nin en çok ziyaret edilen mekânlarından birisi olma özelliğini çalışma konusunun geçtiği dönemde taşımaya devam etmiştir. Bu halin korunması ve geliştirilmesi adına pek çok makale ve haber dönemin kent basınında kendisine yer bulmuş, halk tarafından ilgi ile takip edilmiştir.

Dönemin Konya'sı günümüz ulaşım konforunun pek çoğundan mahrum olmakla birlikte, sıklıkla ziyaret edilen bir merkez olmuştur. Başkent Ankara'ya yakınlığı ve cazip kültürel dokusu sebebi ile başkente gelmiş olan pek çok devlet adamı günü birlik ziyaretlerle Konya'ya gelmiş ve kenti keşfetmeye çalışmıştır. Gelen yabancı ziyaretçilerinden daima olumlu geri dönüşler alan Konya, bu vesile ile dünyadaki tanınırlığını arttırmıştır.

Konya'nın tarihi, turistik ve kültürel yapısının gerçekleştirilen çalışmalar neticesinde arttırılmaya başlaması ile dünyanın konu ile alakalı etkin kurumlarının da ilgisi şehre yansımıştır. Konya'da gerçekleştirilen UNESCO faaliyetleri bunun örneklerinin başında gelmektedir.

Gerçekleşen pek çok olumlu faaliyetin arasında belki de en önemlisi bölge halkının zaman içerisinde tarihi eser ve turizme bakışının değişmesidir. Bu vesile ile Sille halkının bölgelerine gelen turistleri taciz eden vatandaşları afişe etmeleri ve onlara kendi içlerinde sosyal cezalar vermeleri önemli örneklerden birisidir. Aynı şekilde bulunan tarihi eserleri saklamaya, kaçırmaya çalışanların bölgede ifşası da bir diğer güzel örnek olarak Konya'da görülmüştür.

Bir önder / yetkili, sanatı, kültürü sever ve peşine düşerse, dümen o yöne kırılmış olur ve halk da onu izler. 1960'ların Konya'sında vali işte böyle bir kişidir ve şehrin yönü de tarih, kültür ve sanata doğru olmuştur. Vali Karatekin, kendisine yurt içi ve yurt dışından gelen, pek çoğu oldukça kıymetli hediyeleri Konya müzelerine bağışlayarak kent halkına örnek olmaya 
devam etmiş, yaptığı tüm çalışmalar devlet nezdinde de takdir görerek takdirname ile taltif edilmiştir. Bu durum onu daha da fazla çalışmaya ve üretmeye itmiştir.

Sonuç olarak, 1960-1964 yılları arasında Konya, tarihinden aldığı kültürel mirası arttırma gayreti içerisine girmiştir. Tarihi eserlerin bulunması, korunması, onarılması üzerinde hassasiyetle durulması gereken bir konu olarak addedilmiş ve ciddiyetle takip edilmiştir. Müzecilik ve müzeler önemli hale gelmiş, her ilçede müze açılması konusu adeta bir yarış halini almıştır. Dünyada turizmin gelişmesi ve Konya'nın turizm potansiyelinin anlaşılmaya başlaması ile konu üzerinde ciddi analizler yapılmış, devlet ve özel sektör işbirliğiyle kent turizminin geliştirilmesine çalışılmıştır. Dönemin Konya basını, gerek tarihi eserler ve gerekse turizm konusunda hassas, dikkatli ve azimli bir politika benimsemiş, olumlu adımları överek, tanıtarak destek olmuş, olumsuz durumları da ciddi eleştiriler ile kamuoyuna sunmuş ve çözüm yolları önerilmiştir. Bahsi geçen tüm bu mevzuların aynı dönemde harmanlanması ve halkın da ciddi desteği ile dönemin Konya'sında tarihi eser ve turizm alanında önemli gelişmeler yaşanmış, sonraki yıllar için sağlam temeller atılmıştır. 


\section{KAYNAKÇA}

A- Arşivler

- T.C. Başbakanlık Cumhuriyet Arşivi (BCA)

- T.C. Emekli Sandığı Genel Müdürlüğü Arşivi

B- Gazeteler

- Yeni Konya (1960-64)

- Yeni Meram (1960-64)

- Işık (1961)

- Şehir Postası (1962-64)

C- Kitap ve Makaleler

Ana Britannica, Krippel, Heinrinck, C.13, Ana Yayıncllk, İstanbul, 1989.

BAHAR Hasan - Güngör KARAUĞUZ- Özdemir KOÇAK, Eskiçă̆ Konya Araştırmaları 1, İstanbul 1996.

BERBEROĞLU Metin, Kültür Seviyesi, Yeni Konya, 3 Aralık 1960.

ERDOĞAN Muzaffer, Konya Tarih ve Folklorunda Meram, Yeni Konya, 6 Ocak 1961.

ES Selçuk, Konya ve Civarındaki Civa Madenleri ve Romallardan Kalan Mağaralar, Şehir Postası, 21 Ağustos 1962.

ES, Selçuk, Yıldirımdan Yikılan İnce Minarenin Minaresi Hakkında, Yeni Konya, 28 Nisan 1963.

ES Selçuk, Hükümet Konağı, Şehir Postası, 24 Haziran 1963.

GÜNEŞ Ali, Konya ve Çevresinin Turizm Yönünden İnkışafı Nelere Bağlıdır? Yeni Konya, 9 Mayıs 1961.

HODDER Ian, Çatalhöyük The Leopard's Tale, Thames \& Hudson Ltd., London 2006.

KARABACAK Mestan, Konyalı Bir Folklor Araştırmacısı Dr. Mehmet Önder, Selçuk Üniversitesi Sosyal Bilimler Enstitüsü Basılmamış Yüksek Lisans Tezi, Konya 1993.

KARPUZ Haşim, Türk Kültür Varlıkları Envanteri, C.1, Türk Tarih Kurumu Yayınları, Ankara 2009. KÜÇÜK Durmuş, Eski Klasik Türk Hallları Dokunuyor Akviran'da, Şehir Postası, 6 Ağustos 1962.

KÜÇÜKBEZIRCİ Seyit, Tarihi Eser Kaçakçılığı Üzerine, Şehir Postası, 19 Temmuz 1963.

MELLAART James, The Neolitic Of The Near East, Thames And Hudson, London 1975.

OLGUN İhsan, Mevlâna, Yeni Konya, 8 Aralık 1963.

ÖNDER Mehmet, Meramda Onarlan Bir Eser, Yeni Konya, 5 Eylül 1961.

ÖNDER Mehmet, Konya'da Illk Müze, Yeni Konya, 13 Ekim 1961.

ÖNDER Mehmet, Eski Eserlerimiz, Yeni Konya, 12 Temmuz 1962.

ÖNDER Mehmet, Çatalhüyük Kazlları Üzerine, Yeni Konya, 14 Ağustos 1962.

ÖNDER Mehmet, Gelişen Konya Müzeleri, Yeni Konya, 23 Kasım 1963.

ÖNGE Yılmaz, Mevlana Türbesinin Çini Tezyinatt, Selçuk Üniversitesi 1.Millî Mevlana Kongresi Tebliğler Kitabı, Selçuk Üniversitesi Selçuklu Araştırma Merkezi Yayınları, Konya 1986.

ÖZCAN Ahmet - Mustafa GÖĞER- ve diğerleri - 1984 Sonrası Konya, Dönmez Ofset, Ankara 1988.

SEMIZ Yaşar, Cumhuriyet Döneminde Konya'nın İktisadî Durumu (1923-1960), Milli Mücadeleden Günümüze Konya (1915-1965), C.I, T.C. Konya Valiliği İl Kültür Müdürlüğü Yayınları, Konya 1999.

TUĞRUL Sofu, Devrim Müzesi İçin Birkaç Söz Daha, Yeni Konya, 5 Nisan 1962.

UZ Mehmet Ali, Karatekin,Rebii, Konya Ansiklopedisi, C.5, Konya Büyükşehir Belediyesi Yayınları, Konya 2013.

UZ Mehmet Ali, Önder, Mehmet, Konya Ansiklopedisi, C.7, Konya Büyükşehir Belediyesi Yayınları, Konya 2014.

\section{D- İnternet Kaynakları}

https://en.wikipedia.org/wiki/James_Mellaart.

https://en.wikipedia.org/wiki/Nigel Buxton.

http://filozof.net/ david-henry-french.html.

http://kutuphane.tuik.gov.tr/pdf/0015137.pdf.

https://tr.wikipedia.org/wiki/Raybank.

https://tr.wikipedia.org/wiki/Sedat_Alp. 


\section{EKLER}

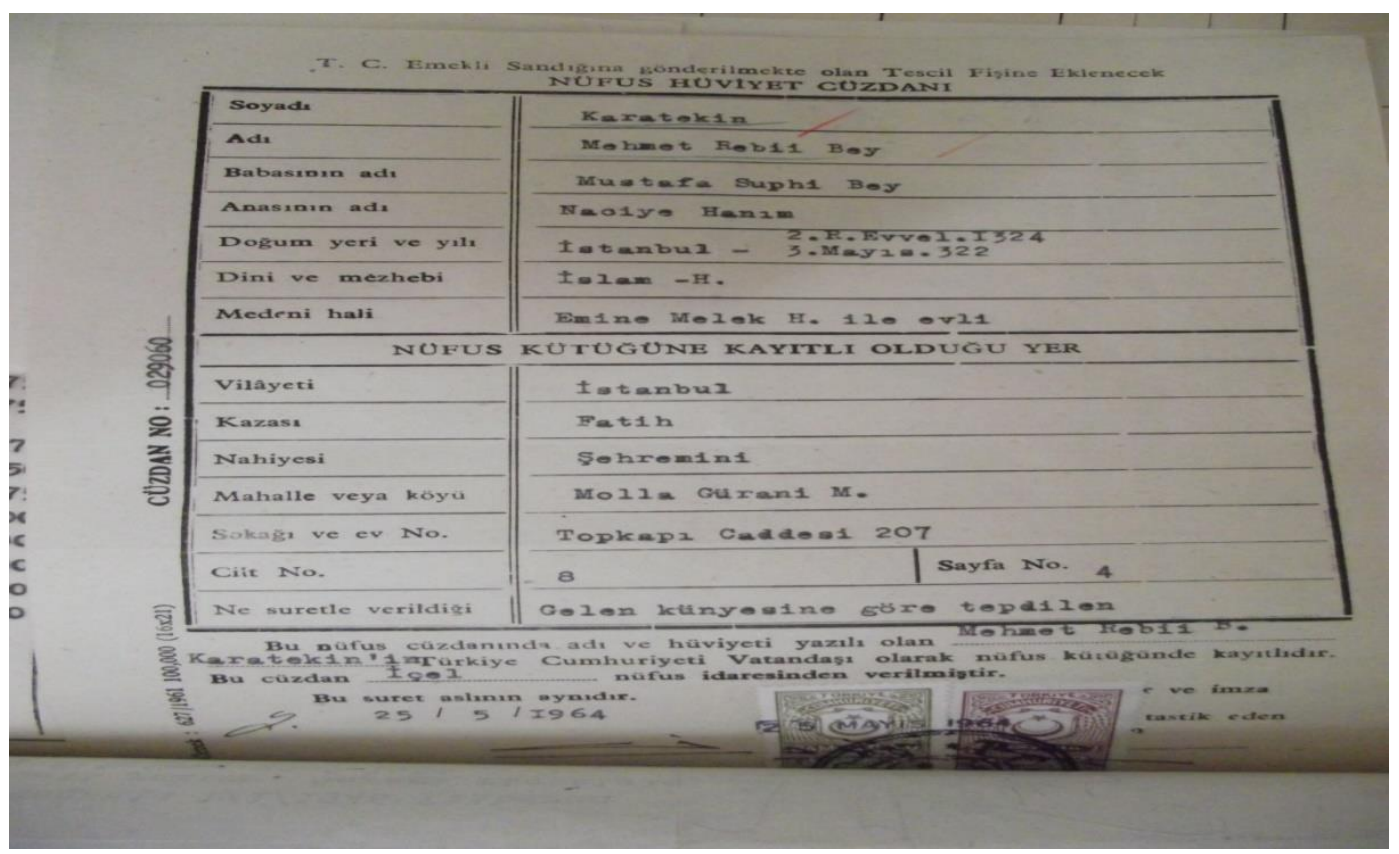

Ek 1: T.C. Emekli Sandığı Genel Müdürlüğü Arşivi: Rebii Karatekin'e Ait Nüfus Hüviyet Cüzdanı.
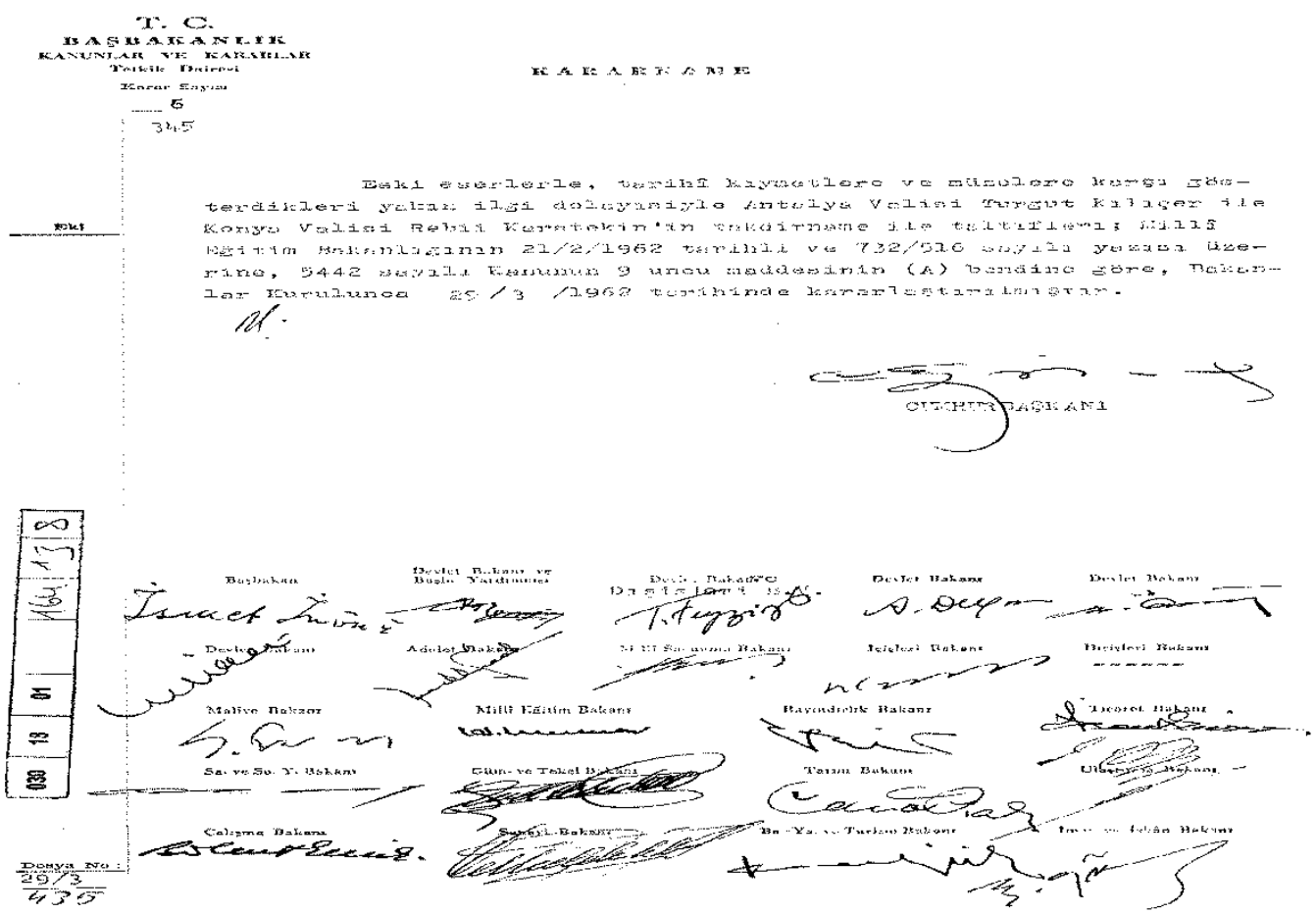

Ek 2: T.C. Başbakanlık Cumhuriyet Arşivi: Vali Rebii Karatekin'in aldı̆̆ı takdirname. 


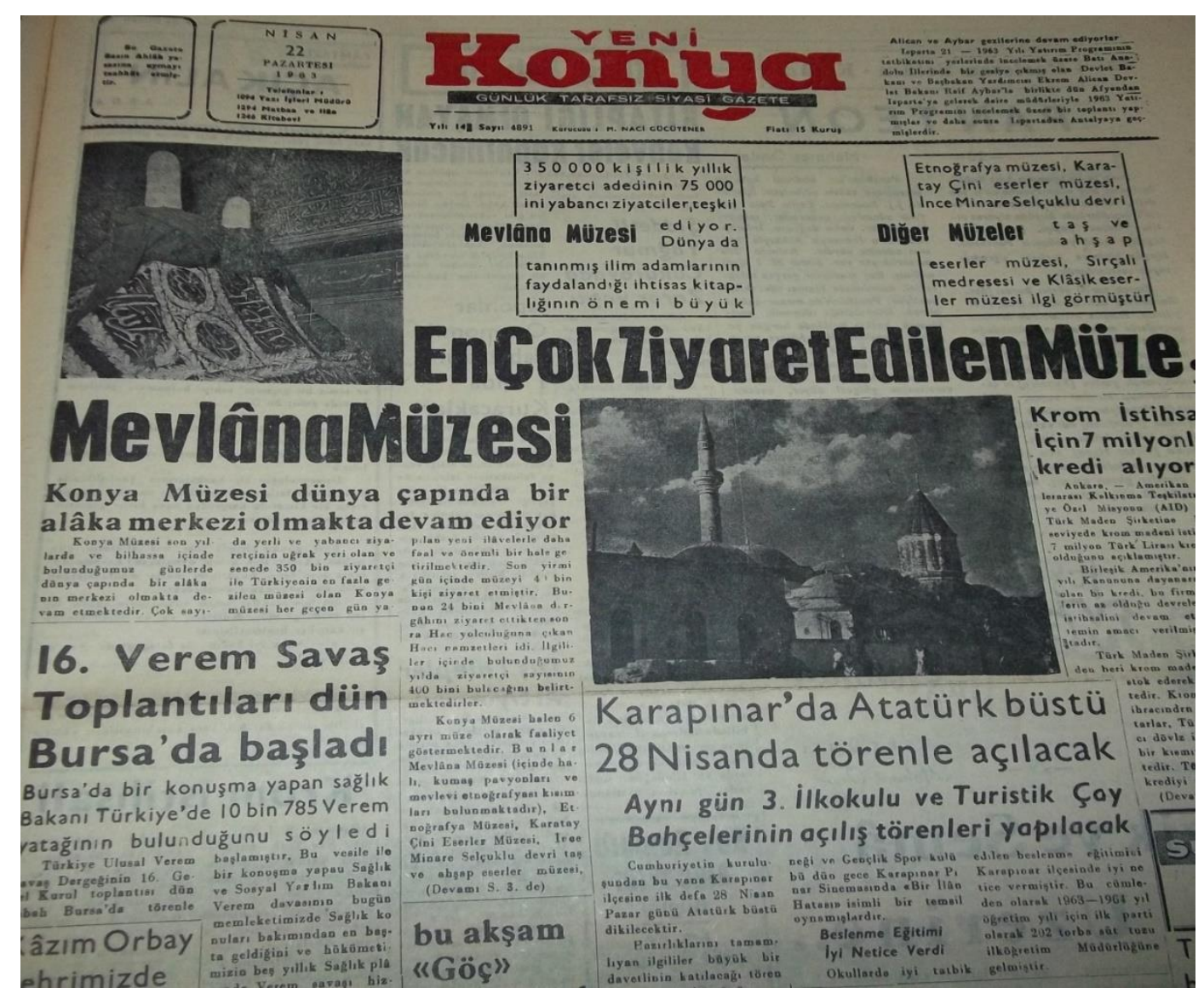

Ek 3: 22 Nisan 1963 tarihli Yeni Konya Gazetesi. 